Research Article

\title{
Deformation and Failure Analyses of the Surrounding Rock Mass with an Interlayer Shear Zone in the Baihetan Underground Powerhouse
}

\author{
Fei Yuan, ${ }^{1}$ An-chi Shi, ${ }^{2}$ Jia-wen Zhou $\mathbb{D}^{1},{ }^{1}$ Wang-bing Hong, ${ }^{2}$ Meng Wang, ${ }^{3}$ Gong-da Lu, ${ }^{1}$ \\ Qin Chen, ${ }^{3}$ and Hai-bo Li $\mathbb{C}^{1}$ \\ ${ }^{1}$ State Key Laboratory of Hydraulics and Mountain River Engineering, Sichuan University, Chengdu 610065, China \\ ${ }^{2}$ PowerChina Huadong Engineering Corporation Limited, Hangzhou, China \\ ${ }^{3}$ College of Water Resource and Hydropower, Sichuan University, Chengdu 610065, China
}

Correspondence should be addressed to Hai-bo Li; 996686010@qq.com

Received 25 August 2021; Revised 11 October 2021; Accepted 13 October 2021; Published 29 October 2021

Academic Editor: Cemal Ozer Yigit

Copyright ( $\odot 2021$ Fei Yuan et al. This is an open access article distributed under the Creative Commons Attribution License, which permits unrestricted use, distribution, and reproduction in any medium, provided the original work is properly cited.

In the process of underground cavern excavation, the existence of the interlayer shear zones or large faults often makes the surrounding rock tend to be unstable or even deformed. Under the influence of interlayer shear zone $\mathrm{C}_{2}$, different degrees of deformation and failure occurred in many parts during the excavation of the Baihetan left bank underground powerhouse. Based on field monitoring and numerical calculation, this paper studies the deformation and failure characteristics of the rock mass with $\mathrm{C}_{2}$ in the whole excavation process and the failure mechanisms are analyzed. The results show that $\mathrm{C}_{2}$ has poor mechanical properties. In the process of excavation, it mainly induces two failure modes: rock collapse and shear deformation, which specifically leads to rock collapses, large deformation and shotcrete cracking in the main powerhouse, and shear deformation in the omnibus bar caves. In addition, the similarities and differences between this study and other studies on the deformation and failure of surrounding rock of underground powerhouse in recent years are discussed, and the relevant treatment measures for $\mathrm{C}_{2}$ are given. The above research results can be a reference for other related studies.

\section{Introduction}

An interlayer shear zone is a poor rock mass system with a loose structure, weak mechanical properties, variable thickness, random distribution, strong extension, and high risk due to the shear motion of rock masses via tectonism, resulting in a variety of stability problems and geological hazards. In particular, there is a potential threat to the overall stability of rock masses with interlayer shear zones in large underground cavern excavations [1-5]. In fact, the existence of weak interlayers and interlayer shear zones causes dam failure, shear slip, and other issues in many projects. For instance, the failure of the Lower Colorado River Dam in Austin (Texas, USA) [6], the Malpasset Dam failure in France [7], the 1963 Vajont landslide in Italy [8], and the large deformation of the main transformer chamber downstream sidewall in Jinping I [9] were related to the influence of weak foundations, faults, or staggered zones. Therefore, interlayer shear zones have currently attracted much attention.

In recent years, many scholars have studied the physical properties, mechanical properties, and induced failure modes of interlayer shear zones. Zhang et al. [10] found that the deformation modulus of soft rock zone under in situ conditions is several times higher than that after the exposure through field tests and laboratory tests. Huang et al. [11] revealed that the existence of weak layers will increase the failure zones and cause stress asymmetrical distribution by physical model test and numerical simulation of tunnel construction. $\mathrm{Xu}$ et al. [12] found through laboratory mechanical tests that the shear behavior between interlayer soil and soil-rock interface was elastic perfect-plastic without 
dilatancy, and the creep phenomenon of interlayer soil in Baihetan underground powerhouse was not significant. Ding et al. [13] analyzed the influence of interlayer shear zone on the stability of arch abutment through dam mechanics model test and finite element method. Cui et al. [14] studied the influence of interlayer shear zone on the seismic stability of tailrace surge chamber based on 3DEC simulation calculation. Duan et al. [15] proposed a comprehensive in situ monitoring scheme for rock mass with interlayer shear zone and analyzed some collapse and plastic extrusion failure problems induced by interlayer shear zone combined with monitoring data and mechanical test results. Zhou et al. [16] revealed the scale effect and value standard of permeability of interlayer shear zone of basalt by numerical and analytical methods. Guo and Huang [17] analyzed the seepage characteristics of interlayer shear zone $C_{2}$ in underground powerhouse area by finite element groundwater flow system. Zhao et al. [18] studied the fracture process and mechanism of rock mass with interlayer shear zones in cross caverns during excavation in combination with microseismic monitoring technology. Cheng et al. [19] studied the layout design of concrete replacement tunnels for interlayer shear zone. Liu et al. and Jin et al. [20,21] studied the repair technology of weak interlayer based on microbially induced calcium carbonate precipitation and proved that this technology can improve the relevant mechanical properties of weak interlayer through mechanical tests. Shi et al. [22] found that unloading shear deformation of the interlayer shear zone of the left dam foundation of Baihetan would bring instability risk to the dam foundation by in situ tests and numerical analysis, and they put forward some reinforcement measures. However, few studies have systematically examined and analyzed geological problems caused by the interlayer shear zone during the whole excavation progress of the underground powerhouse.

In the basalt layer of the Late Permian Emeishan Formation on the left bank of the Baihetan Hydropower Station, there is an interlayer shear zone, $\mathrm{C}_{2}$, which obliquely cuts through underground caverns. Because of its long penetration, strong dislocation, and poor properties, it has a huge impact on the stability of the surrounding rock masses. For instance, the main powerhouse sidewall experienced a sudden increase in deformation, and shotcrete cracks appeared in the omnibus bar caves when $\mathrm{C}_{2}$ was exposed during excavation. Taking the Baihetan left bank underground powerhouse as a case study, this paper studies the deformation and failure of a rock mass affected by the interlayer shear zone $\mathrm{C}_{2}$. The conclusions are expected to provide a reference for the design, optimization, and construction of similar projects.

\section{Background}

2.1. The Baihetan Underground Powerhouse. The Baihetan Hydropower Station is in the second cascade in the four cascade power stations of Wudongde, Baihetan, Xiluodu, and Xiangjiaba on the lower reaches of the Jinsha River [23]. The left bank of the Baihetan Hydropower Station belongs to Ningnan County, Sichuan Province, and the right bank belongs to Qiaojia County, Yunnan Province (Figure 1(a)). The normal storage level of the power station reservoir is $825 \mathrm{~m}$. The total installed capacity of the power station is 16,000 MW [24]. After completion, it will be the second largest hydropower station in the world after China's Three Gorges project, with an average power generation capacity of 62.443 billion $\mathrm{kW} . \mathrm{h}$.

As shown in Figure 1(b), the underground caverns on the left bank of the Baihetan Hydropower Station include the main powerhouse, the transformer chamber, the draft tube bulkhead gate chamber, four tailrace surge chambers, four tailrace tunnels, eight diversion tunnels, eight draft tube tunnels, and eight omnibus bar caves. Four main caverns (the main powerhouse, the transformer chamber, the draft tube gate chamber, and the tailrace surge chambers) are arranged in parallel, and all the chambers have the same axis direction of $\mathrm{N} 20^{\circ} \mathrm{E}$. The dimensions of the main powerhouse are $438 \mathrm{~m} \times 34 \mathrm{~m} \times 88.7 \mathrm{~m}$ (length $\times$ width $\times$ height), and the main transformer chamber is $368 \mathrm{~m} \times 21 \mathrm{~m} \times 38.5 \mathrm{~m}$. The distance between the main powerhouse and the transformer chamber is $59.15 \mathrm{~m}$. The length of the draft tube gate chamber is $374.5 \mathrm{~m}$, the span is $12.1-15.0 \mathrm{~m}$, and the height is 30.5-31.5 m. The excavation diameter of the tailrace surge chamber is $42-48 \mathrm{~m}$. The main powerhouse was excavated in ten layers from layer I to layer X (Figure 1(c)). The excavation of the first layer was begun in May 2014, and the overall excavation was completed in June 2018. The main transformer chamber was excavated in four layers from layer I to layer IV. The excavation of the first layer was begun in July 2014, and the overall excavation was completed in September 2016. In addition, to address the adverse effects of interlayer shear zone $\mathrm{C}_{2}$ on the stability of the powerhouse, concrete replacement was carried out for $\mathrm{C}_{2}$ near the upstream and downstream sides of the powerhouse and for the rock masses in the zone affected by $\mathrm{C}_{2}$ before the main powerhouse excavation.

2.2. Geological Conditions. The underground powerhouse area on the left bank is located in the upper mountain of the dam abutment, with a horizontal buried depth of $600-1000 \mathrm{~m}$ and a vertical buried depth of $260-330 \mathrm{~m}$. As shown in Figure 2(a) and 2(b), the strata along the left bank underground power station are monoclinic, with a $\mathrm{N} 42^{\circ}$ $45^{\circ} \mathrm{E}$ strike, a SE dip direction, and a $15^{\circ}-20^{\circ}$ dip angle. The main strata from upper to lower are $P_{2} \beta_{2}^{4}, P_{2} \beta_{2}^{3}, P_{2} \beta_{3}^{2}, P_{2} \beta_{3}^{1}, P_{2} \beta_{2}^{3}, P_{2} \beta_{2}^{2}$, etc. $\left(P_{2} \beta\right.$ refers to the Upper Permian Emeishan basalt group, and other indexes refer to different lithologic layers). The lithology includes cryptocrystalline basalt, oblique tholeiite, amygdaloidal basalt, breccia lava, and tuff. The thickness of the tuff in $P_{2} \beta_{2}^{4}$ is $60-80 \mathrm{~cm}$, and the tuff is weak and easily softens in water.

The faults developed in the underground powerhouse on the left bank are generally small in scale, consisting of hard structural planes and rock debris types. They have some common features, such as strikes of $\mathrm{N} 40^{\circ}-70^{\circ} \mathrm{W}$ and steep dip angles beyond $75^{\circ}$. The main developed faults are $f_{717}, f_{718}$, $f_{719}, f_{720}, f_{721}, f_{722}$, and $f_{723}$, with widths of $5-20 \mathrm{~cm}$. The materials in the belt are mainly jointed structural rocks and 


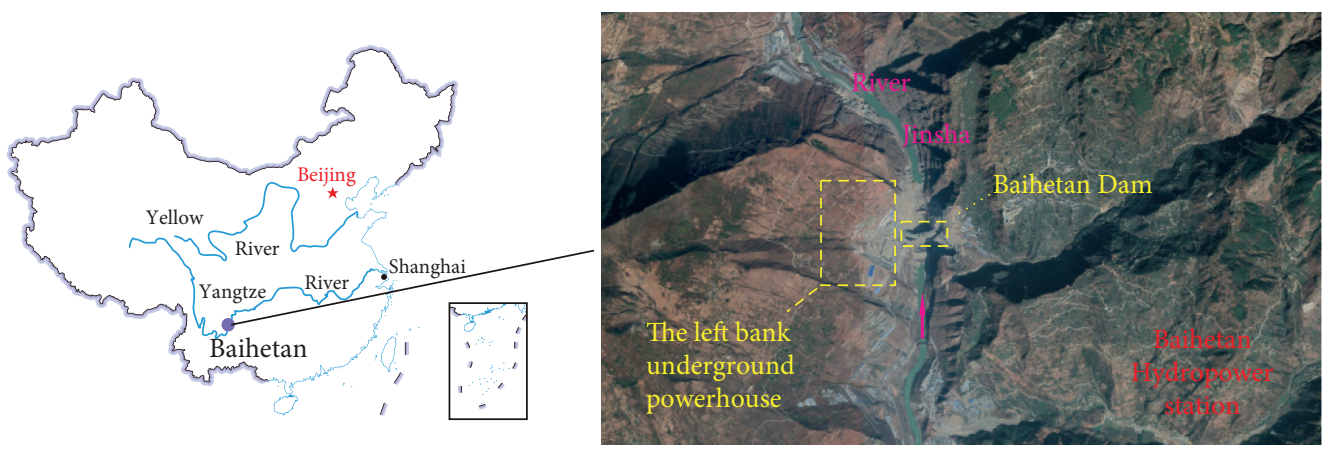

(a)

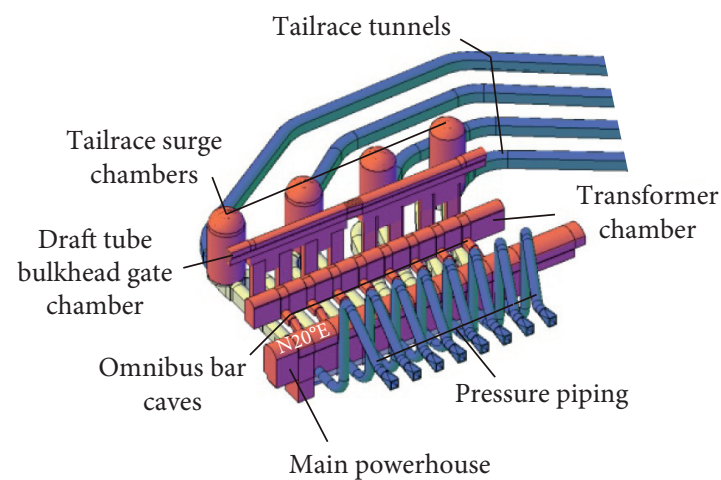

(b)

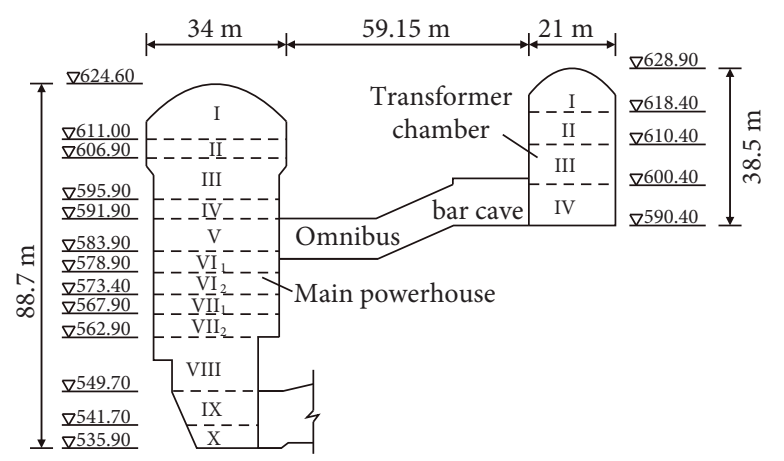

(c)

FIGURE 1: Site location and three-dimensional visualization of the Baihetan underground powerhouse and excavation layering diagram: (a) locations of the Baihetan Hydropower Station; (b) three-dimensional visualization of the left bank underground powerhouse; (c) a layered excavation diagram of the main powerhouse and transformer chamber (I-X refer to the layer numbers).

structural breccia. The interlayer shear zone $\mathrm{C}_{2}$ develops along the middle $P_{2} \beta_{2}^{4}$ tuff, with a $42^{\circ}-45^{\circ}$ E strike, a SE dip direction, and a $15^{\circ}-20^{\circ}$ dip angle (Figures $2(\mathrm{c})$ and $2(\mathrm{~d})$ ). The internal staggered zones are mainly developed in $P_{2} \beta_{3}^{2}$ and $P_{2} \beta_{3}^{3}$. They are mainly small-scale rock fragments and hard structural planes. On the left bank, the main developed internal staggered zones are $\mathrm{LS}_{3152}$ and $\mathrm{LS}_{3255}-\mathrm{LS}_{3257}$. The cracks can be divided into long cracks and random cracks. The former are 50-100 $\mathrm{m}$ long hard structural planes with a $\mathrm{N} 40^{\circ}-60^{\circ} \mathrm{W}$ strike, $65^{\circ}-85^{\circ}$ dip angle, and $10-30 \mathrm{~m}$ wide spacing. Random cracks mainly developed in three groups with steep dip angles: (1) a strike of $\mathrm{N} 30^{\circ}-70^{\circ} \mathrm{W}$, dip direction of SW, and dip angle of $65^{\circ}-90^{\circ}$; (2) a strike of $\mathrm{N} 20^{\circ}-50^{\circ} \mathrm{E}$, dip direction of SE, and dip angle of $10^{\circ}-35^{\circ}$; and (3) a strike of $\mathrm{N} 50^{\circ}-70^{\circ} \mathrm{E}$, dip direction of SE, and dip angle of $50^{\circ}-60^{\circ}$. The first group of cracks is dominant, and the proportion of cracks in the other directions is small. The length of the cracks is $2-5 \mathrm{~m}$, the width is generally less than $1 \mathrm{~cm}$, and the spacing is generally $50-200 \mathrm{~cm}$. The cracks are mostly fresh and closed, straight and rough, and a few are filled with calcium film.

The in situ stress on the plant area on the left bank is mainly tectonic stress, and the horizontal stress is greater than the vertical stress. As shown in Figure 3, the first principal stress $\left(\sigma_{1}\right)$ is approximately $19-23 \mathrm{MPa}$, with a direction of $\mathrm{N} 30^{\circ}-50^{\circ} \mathrm{W}$ and a dip angle of $5^{\circ}-13^{\circ}$. The angle between the directions of the first principal stress and the axis of the underground powerhouse cavern is approximately $50^{\circ}-70^{\circ}$. The magnitude of the second principal stress $\left(\sigma_{2}\right)$ is $13-16 \mathrm{MPa}$. The direction of the third principal stress $\left(\sigma_{3}\right)$ is basically vertical, with a magnitude of 8.2-12.2 MPa, which is equivalent to the overburden of the overlying rock mass. The average uniaxial saturated compressive strength $R_{b}$ of the rock in the underground powerhouse is $74-112 \mathrm{MPa}$, and the strength/stress ratio $\left(R_{b} / \sigma_{1}\right)$ of the rock is 3.22-5.89. In addition, there is an initial stress concentration area with a range of approximately $10-40 \mathrm{~m}$ in the footwall of the interlayer shear zone $\mathrm{C}_{2}$, and the maximum stress can reach more than $30 \mathrm{MPa}$, which can be categorized as a high in situ stress area.

2.3. Interlayer Shear Zone. Interlayer shear zones are a kind of thin and banded rock mass system. Under interlaminar shear dislocation due to tectonic action, the soft rock mass is altered, and its structure was disturbed. As a result, an interlayer shear zone is formed. Interlayer shear zones feature loose structure, weak properties, multiple layers, variable thickness, random distribution, and strong extension. Therefore, rock masses with interlayer shear zones are prone to stability problems and geological disasters. Many slopes, dam foundations, and underground projects have experienced deformation or failure problems due to the existence of interlayer shear zones [25].

There are many interlayer shear zones in the tuffaceous layer at the top of the basalt flow layer in the Baihetan plant 


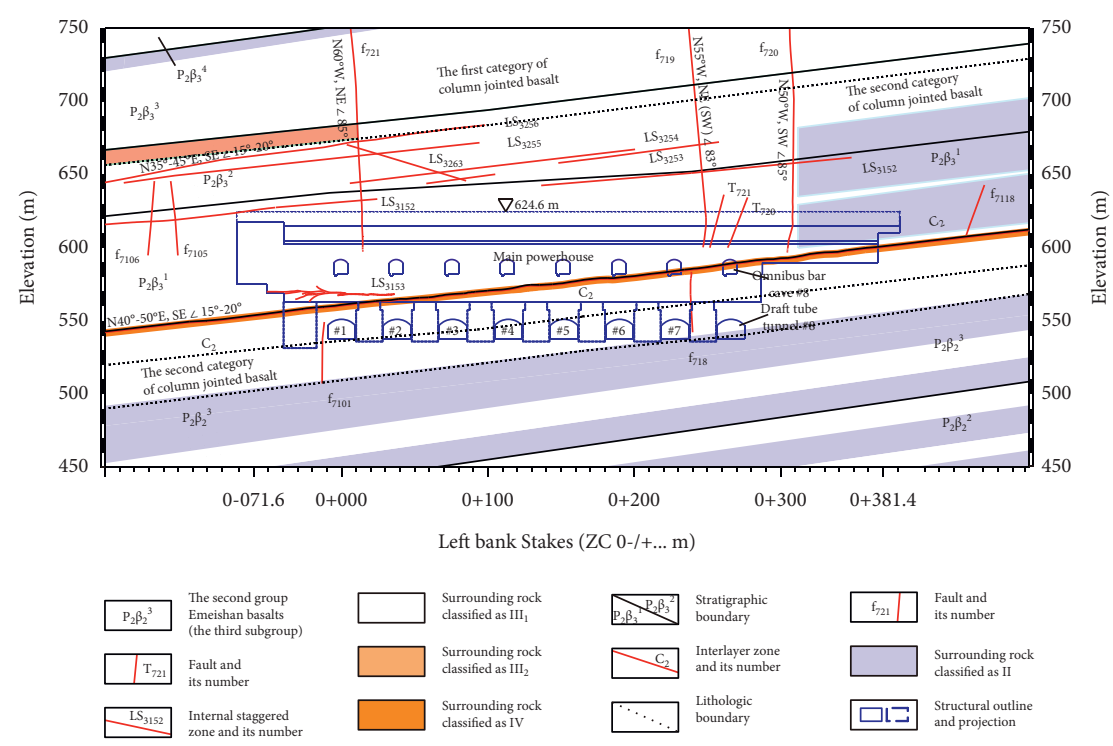

(a)

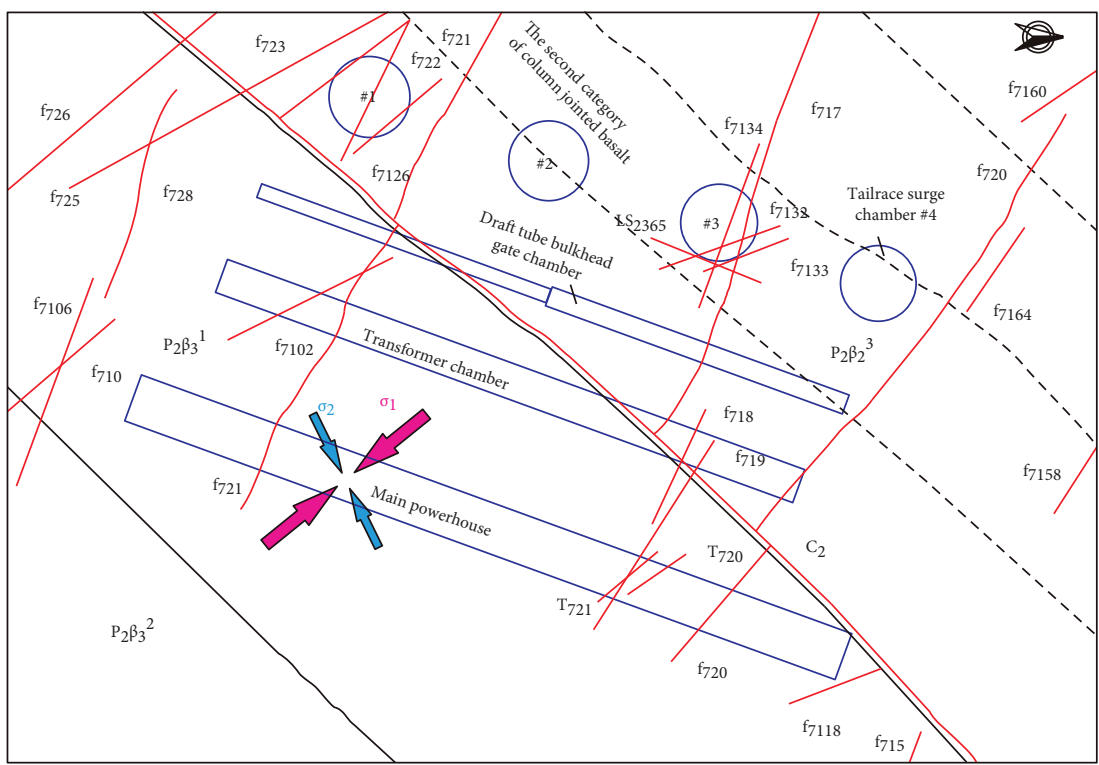

(b)
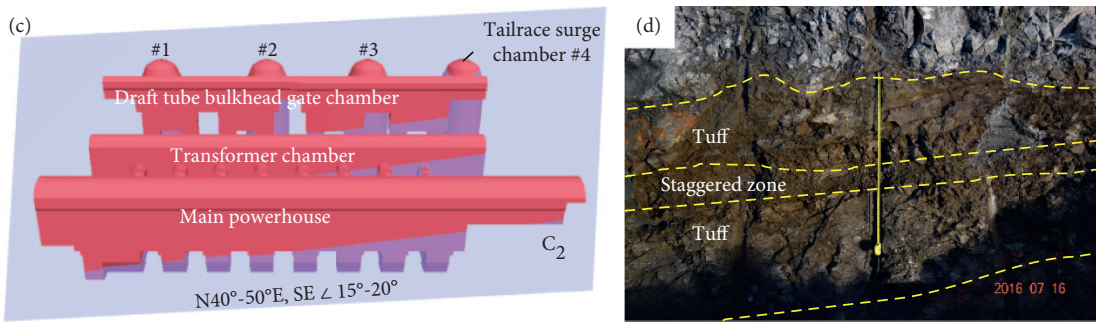

Figure 2: Geological conditions of the Baihetan left bank underground powerhouse: (a) a geological cross section of the left bank main powerhouse along the downstream sidewall; (b) a geological cross section of the main power house on the left bank along the $602 \mathrm{~m}$ elevation; (c) a spatial layout diagram of the interlayer shear zone $\mathrm{C}_{2}$; (d) typical characteristics of $\mathrm{C}_{2}$.

area, $\mathrm{C}_{2}$ on the left bank and $\mathrm{C}_{3}, \mathrm{C}_{3-1}, \mathrm{C}_{4}$, and $\mathrm{C}_{5}$ on the right bank, which were all formed during the long process of tectonic movement. During the tectonic movement dominated by the Yanshanian inversion and the Himalayan orthodox, interlaminar dislocation occurred in the
Emeishan basalt flow layer with alternating soft and hard rocks. The weak tuff formation at the top of the rock flow layer was broken by tectonic stress, and an interlayer compression shear zone was formed. In the initial tectonic stage, the complete basalt and tuffaceous rock mass was 


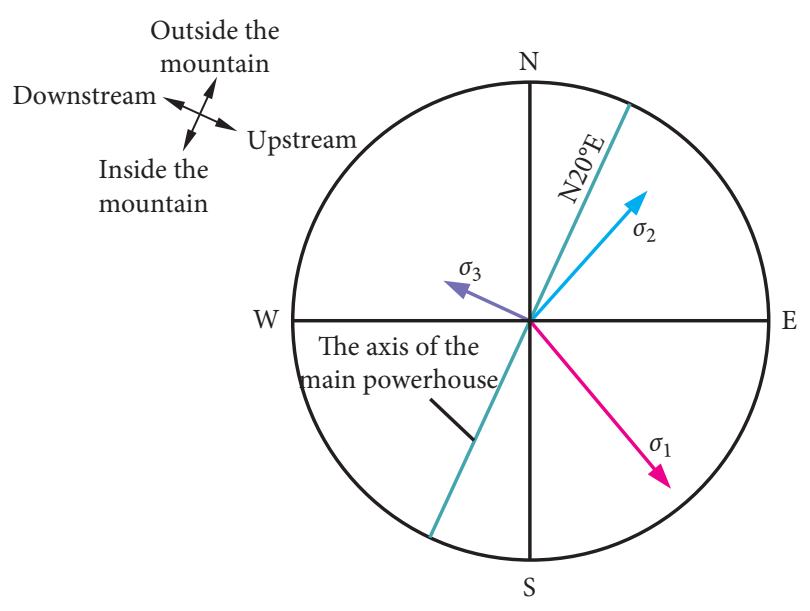

FIgURE 3: Schematic diagram of the initial in situ stresses of the left bank underground powerhouse.

fractured into a joined rock mass with uniform arrangement, which was the upper and lower walls of the dislocation zone. After long-term geological tectonic action and physical and chemical transformation caused by groundwater, most of the joint zones subjected to compression and shear were further fragmented and argillized. Finally, a cleavage zone and argillaceous zone were formed, which are the main parts of the interlayer shear zone. The tuff joint zone is less affected by geological transformation, so it maintains the physical state of the rock. However, the cleavage zone and argillaceous zone are highly fragmented and argillaceous, thus presenting the physical state of the soil [26].

$\mathrm{C}_{2}$ developed along the middle part of $P_{2} \beta_{2}^{4}$. Its overall thickness is $10-60 \mathrm{~cm}$, and the average thickness is approximately $20 \mathrm{~cm}$. The material in $\mathrm{C}_{2}$ is mainly cleavage tectonic rocks and locally brecciated structural rocks. $\mathrm{C}_{2}$ is composed of mud and rock fragments, and it easily softens when in contact with water. The thickness of the tuff in the hanging wall is $10-40 \mathrm{~cm}$, and that in the footwall is $20-40 \mathrm{~cm}$. Argillaceous strips with thicknesses of $0.5-3.0 \mathrm{~cm}$ can be seen at the upper and lower interfaces (Figure 2(d)). Shear joints developed in the tuff, and the dip direction of the joints was nearly perpendicular to the rock strike. The surface of the joints is smooth and scratched. The spacing of the joints is $5-50 \mathrm{~m} . \mathrm{C}_{2}$ is extensively exposed in the underground caverns on the left bank. As mentioned above, four main caverns have the same axis direction of $\mathrm{N} 20^{\circ} \mathrm{E}$ and the strike of $\mathrm{C}_{2}$ is $\mathrm{N} 42^{\circ}$ $45^{\circ} \mathrm{E}$. The intersection angle between them is about $20^{\circ} . \mathrm{C}_{2}$ not only obliquely cuts the middle and lower parts of the sidewall of the powerhouse but also cuts through the middle and lower parts of the sidewall of the main transformer chamber, the shaft section of the draft tube gate chamber, and the middle and upper parts of tailrace surge chambers \#1-4 (Figure 2(c)). $\mathrm{C}_{2}$ provides a potential slip surface for the shear dislocation of surrounding rock. At the same time, the direction of the first principal stress $\left(\mathrm{N} 30^{\circ}-50^{\circ} \mathrm{W}\right)$ intersects the axis direction of the powerhouse at a large angle. Therefore, the sidewall is prone to shear deformation along the direction perpendicular to the powerhouse's axis in the process of excavation. In addition, the combination of cracks, steep and gently inclined fractures, free faces, and $\mathrm{C}_{2}$ cut the rock mass into many unstable blocks. These unstable blocks may cause collapse or other failure problems during the excavation and unloading. According to the classification standard of surrounding rock in the "Code for Hydropower Engineering Geology" (GB 50287-2016) [27], the rock mass with $C_{2}$ is classified as IV (Figure 2(a)). On the basis of the RMR classification method, the value of RMR for $C_{2}$ is $21-40$ [28, 29].

To explore the mechanical properties of $\mathrm{C}_{2}$, this study conducted laboratory direct shear tests, field conventional shear tests, and field deformation tests. The consolidation fast shear method was adopted in the indoor direct shear test, with four specimens in each group. The specimens were saturated with tap water, and the shear rate had a minimum value of $0.8 \mathrm{~mm} / \mathrm{min}$. The specimens were sheared within 3-5 min. The indoor direct shear tests showed that the average cohesion $c$ was approximately $22.57 \mathrm{kPa}$, and the average internal friction angle $\varphi$ was approximately $19.5^{\circ}$. The direct shear method was used in the field conventional shear test. After applying a constant normal stress at each stage, the shear stress was increased continuously until the rock mass showed shear failure. The test sites were in the typical detection adits in the plant area. The results of the field tests showed that the average cohesion $c$ was approximately $60 \mathrm{kPa}$ and the average friction angle $\varphi$ was approximately $14.57^{\circ}$. The rigid pressure plate method was adopted in the field deformation test by using a $50.5 \mathrm{~cm}$ diameter rigid pressure plate. The load was applied by the jack with a maximum load capacity of 6-8 MPa. The deformation of the rock mass was measured by four dial gauges symmetrically mounted on the pressure plate. The field test results showed that the average deformation modulus of weak materials in $\mathrm{C}_{2}$ was $0.04 \mathrm{GPa}$, and the comprehensive deformation modulus of the weak materials and tuff rock mass in the upper and lower plates was $0.19 \mathrm{GPa}$. Most related test results also showed that the cohesion of $\mathrm{C}_{2}$ was small, the shear strength was low, and the ability to resist deformation was weak $[26,30]$.

Based on the field investigation and related experimental analysis of $\mathrm{C}_{2}$, the engineering characteristics of $\mathrm{C}_{2}$ are summarized as follows:

(a) $C_{2}$ is extensively exposed in many caverns. The exposed length is tens of meters or even hundreds of meters, which will affect the stability of the surrounding rock during the excavation of these caverns.

(b) The underground powerhouse on the left bank of the Baihetan Hydropower Station is located in a high in situ stress environment, and $\mathrm{C}_{2}$ is strongly affected by the rock pressure generated during geological history. Under long-term extrusion, the internal structure of $\mathrm{C}_{2}$ becomes more compact. When the caverns are excavated and unloaded, $\mathrm{C}_{2}$ will be plastically squeezed out from the free face.

(c) The special "hard-soft-hard" rock structure of $\mathrm{C}_{2}$ makes it possible to slip along the upper and lower 
interfaces. The field investigation results show that the occurrence of many shear slip planes in $\mathrm{C}_{2}$ is almost consistent with that of the rock strata, and linear scratches and mirror surfaces are widely distributed on these shear slip surfaces. This observation confirms the multiple shearing actions that have occurred throughout geological history. The existence of shear slip surfaces also reduces the shear strength of $\mathrm{C}_{2}$. Therefore, the shear dislocation of $\mathrm{C}_{2}$ is likely to be a stability issue under excavation disturbance.

(d) $C_{2}$ shows significant softening in water. The analysis of the composition of $\mathrm{C}_{2}$ suggests that it contains many clay minerals, such as illite, and exhibits strong swelling potential, poor resistance to disintegration, and obvious deterioration when encountering water [31].

\section{Failure Characteristics Analysis}

The special engineering geological characteristics of $\mathrm{C}_{2}$ affect the integrity and stability of the surrounding rock masses of the underground caverns and pose a threat to safe construction. As mentioned above, before the excavation of the powerhouse, the project builders arranged deep sheeringresistance tunnels and shallow sheering-resistance branch tunnels to make concrete replacements and reinforcements for $\mathrm{C}_{2}$ and the rock masses within its influence zone near the upstream and downstream sides of the powerhouse. However, during the excavation process, a series of deformation and failure problems of the surrounding rock masses still appeared in the caverns, for example, in the main powerhouse and the other caverns affected by $\mathrm{C}_{2}$.

3.1. Rock Collapses. During the excavation process of the underground powerhouse, there were different degrees of rock mass collapse near the exposed parts of $\mathrm{C}_{2}$ in many caverns, including the main powerhouse, the main transformer chamber, the draft tube gate chamber, the tailrace surge chambers, and the omnibus bar caves.

The combination of $\mathrm{C}_{2}$ and steep cracks and columnar joints that developed in the upstream and downstream sidewalls of the main powerhouse resulted in small-scale rock collapse in these parts. The length of most of the collapse areas was generally $4-10 \mathrm{~m}$, the width was $0.3-5.5 \mathrm{~m}$, and the depth was $0.3-2.0 \mathrm{~m}$. The typical collapse features in the powerhouse are shown in Figure 4.

During the excavation of the main transformer chamber, some upstream and downstream sidewalls collapsed along $\mathrm{C}_{2}$. The length of most of the collapse areas was generally $3-8 \mathrm{~m}$, the width was $2-5 \mathrm{~m}$, and the depth was generally $30-50 \mathrm{~cm}$. The typical collapse features in the main transformer chamber are shown in Figure 4(a).

As shown in Figure 4, during construction, different degrees of rock collapse also occurred where $C_{2}$ was exposed in other caverns. $\mathrm{C}_{2}$ was exposed at the arch crown of omnibus bar cave \#8, where collapse occurred in the footwall rock masses. The length of the collapse area was $11-15 \mathrm{~m}$, the width was $9 \mathrm{~m}$, and the depth was generally $50-150 \mathrm{~cm}$. Due to the exposure of $\mathrm{C}_{2}$ in the sidewalls of the draft tube gate chamber, rock collapses appeared along $\mathrm{C}_{2}$ at the sidewalls of the gate chamber and along \#1,\#2,\#3, and \#7 gate shafts. The length of most collapse areas was generally 3-5 m, while that of a few areas was up to $22 \mathrm{~m}$, the width was $2-5 \mathrm{~m}$, and the depth was $20-80 \mathrm{~cm}$. For the collapse area of the upstream sidewall at elevations of 598-603 m of gate well \#3, the length was 3-4 m, the width was $5 \mathrm{~m}$, and the depth was $10-60 \mathrm{~cm}$. Because $C_{2}$ was exposed in tailrace surge chambers \#1-4, the vertical walls of \#1 and \#2 collapsed along $C_{2}$. The length of most collapse areas was 4-6 m, while that of a few areas was up to $11 \mathrm{~m}$, the width was $1-2 \mathrm{~m}$, and the depth was $30-50 \mathrm{~cm}$.

\subsection{Large Deformation and Shotcrete Cracking in the Main} Powerhouse. According to the research results and extensive engineering experience, the deformation greater than $50 \mathrm{~mm}$ can be defined as the large deformation of the surrounding rock of Baihetan underground powerhouse [9]. With the excavation of the powerhouse, the exposed face of $\mathrm{C}_{2}$ increased. During the excavation of layer $\mathrm{VII}_{2}$ of the powerhouse, the displacement measured by several multipoint extensometers increased sharply from August 2 to 9, 2017, and these extensometers were arranged along $C_{2}$ in the downstream sidewall (the section from stake $\mathrm{ZC} 0+077 \mathrm{~m}$ to $\mathrm{ZC} 0+181 \mathrm{~m})(\mathrm{ZC}$ refers to the left bank powerhouse, and $0+316$ indicates the section position). The displacement increased by $6.70-37.47 \mathrm{~mm}$ in $5-7$ days, and the average growth rate was approximately $0.96-7.49 \mathrm{~mm} / \mathrm{d}$. The multipoint extensometer $\mathrm{M}_{\mathrm{ZC}} 0+124-3$ was located at an elevation of $574.5 \mathrm{~m}$ on the downstream sidewall (section $\mathrm{ZC} 0+124 \mathrm{~m}$ ), which was located approximately $2.5 \mathrm{~m}$ above $\mathrm{C}_{2}$. The layout of multipoint extensometer $\mathrm{M}_{\mathrm{ZC}} 0+124-3$ and the curves of displacement measured at different depths with time are shown in Figure 5(a).

As shown in Figure 5(b), from May 5 to August 2, 2017, the displacement measured at different depths increased slowly by $1.61-19.90 \mathrm{~mm}$. From August 2 to 9, 2017, the displacement of each measuring point increased sharply, with the displacement increasing by $17.85-30.52 \mathrm{~mm}$. In particular, the displacement measured at $1.5 \mathrm{~m}$ increased from $19.47 \mathrm{~mm}$ to $49.90 \mathrm{~mm}$ within 7 days, with an average growth rate of approximately $4.35 \mathrm{~mm} / \mathrm{d}$. When the displacement mutation occurred, the powerhouse was excavated to $\mathrm{EL} 562.9 \mathrm{~m}$, and $\mathrm{C}_{2}$ was exposed at this section. From August 9, 2017, to July 2018, the displacement growth rate gradually slowed down, showing stable growth. The displacement increment of each measuring point was 23.63-33.14 mm, and the displacement measured at a depth of $1.5 \mathrm{~m}$ increased to $83.04 \mathrm{~mm}$. After July 2018, with the completion of the powerhouse excavation, the displacement growth slowed significantly and showed a trend of convergence; finally, the cumulative displacement of each depth measuring point was $42.91-83.89 \mathrm{~mm}$.

Except for the sudden increase in displacement measured by $\mathrm{M}_{\mathrm{ZC}} 0+124-3$, the displacement measured by several multipoint extensometers arranged along $\mathrm{C}_{2}$ in the 


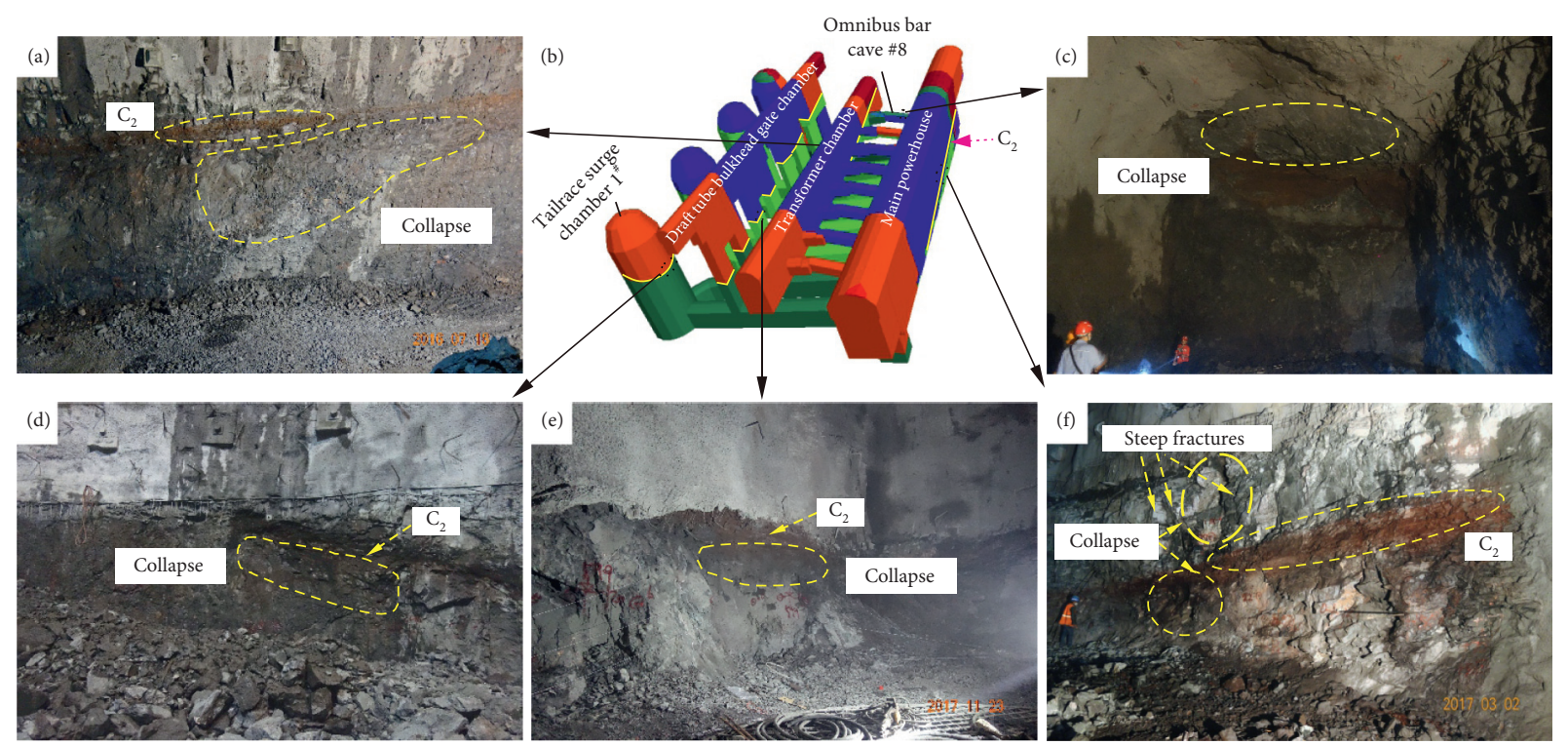

FIgURE 4: Rock collapses occurred along $\mathrm{C}_{2}$ in the underground powerhouse: (a) the downstream sidewall of layer IV of the transformer chamber; (b) a schematic diagram of the rock mass collapse position; (c) the crown arch of omnibus bar cave \#8; (d) the shaft section of tailrace surge chamber \#1; (e) the upstream sidewall of gate shaft \#3; (f) the downstream sidewall of layer $\mathrm{VI}_{2}$ of the main powerhouse section from $\mathrm{ZC} 0+156 \mathrm{~m}$ to $\mathrm{ZC} 0+145 \mathrm{~m}$.
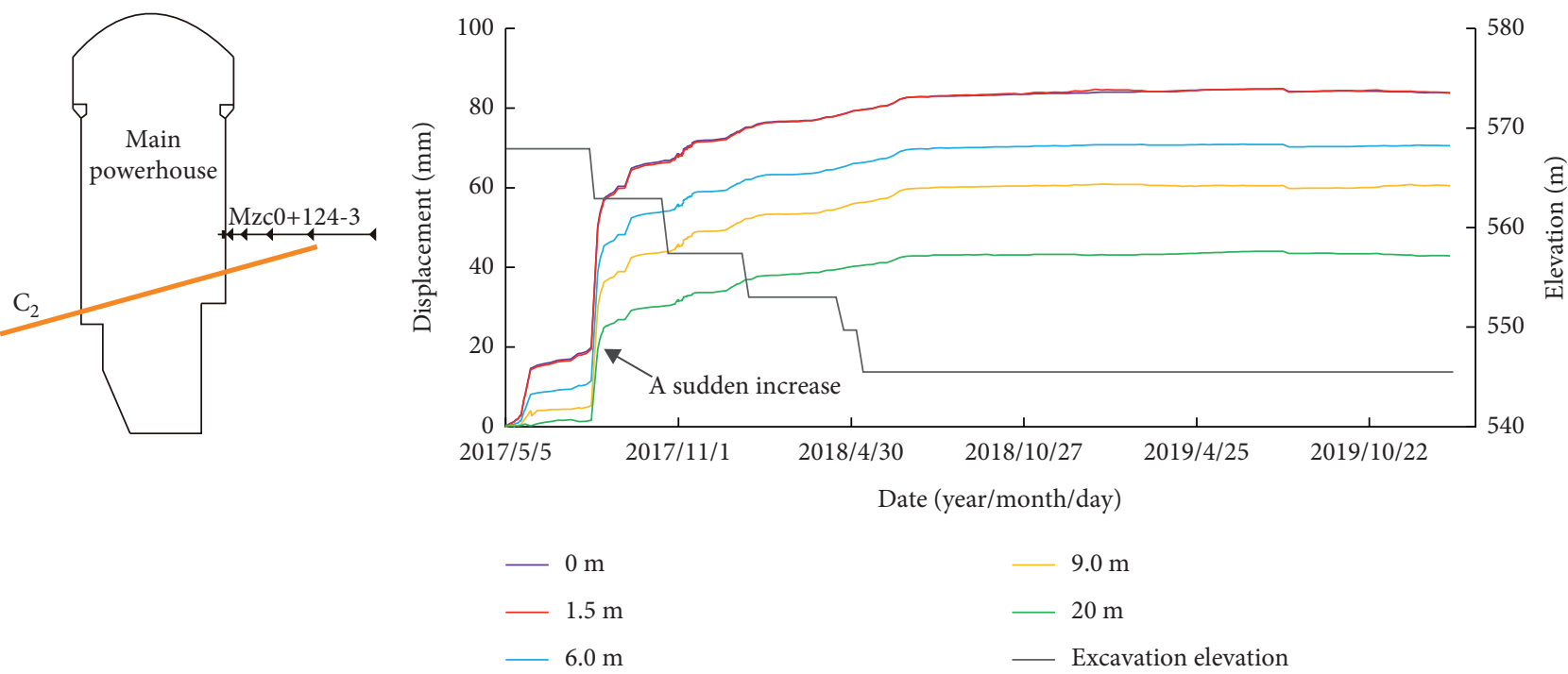

(a)

(b)

FIGURE 5: The position schematic diagram of multipoint extensometer and the displacement-time curves: (a) layout of multipoint extensometer $\mathrm{M}_{\mathrm{ZC}} 0+124-3$; (b) the displacement-time curves measured by multipoint extensometer $\mathrm{M}_{\mathrm{ZC}} 0+124-3$.

downstream sidewall (the section from stake $\mathrm{ZC} 0+077 \mathrm{~m}$ to $\mathrm{ZC0}+181 \mathrm{~m}$ ) increased sharply from August 2 to 9, 2017. The buried elevation of these instruments was in the range of $570-582 \mathrm{~m}$, and the exposed elevation of $\mathrm{C}_{2}$ on the sidewall was 567.9-579 $\mathrm{m}$, indicating a vertical distance between the instruments and $\mathrm{C}_{2}$ of approximately $0.9-12 \mathrm{~m}$. After the sudden increase in displacement, the cumulative deformation of the sidewall was $32.52-83.93 \mathrm{~mm}$. The overall deformation was large, and the statistics of the sudden increase in displacement measured by different multipoint extensometers are shown in Table 1. The deformation of the surrounding rock was generally large at positions close to $\mathrm{C}_{2}$. In contrast, the deformation of the corresponding part of the upstream sidewall of the same section had no sudden change, and the deformation was generally less than that of the downstream side.

When the main powerhouse was excavated to layer $\mathrm{VII}_{2}$ on August 10, 2017, the shotcrete cracked and swelled on the downstream sidewall of the section from stake ZC0 + 134 to $\mathrm{ZC} 0+163 \mathrm{~m}$, and the cracks extended along $\mathrm{C}_{2}$, as shown in 
TABLE 1: Statistics of the sudden increase in downstream sidewall deformation in the main powerhouse measured by multipoint extensometers near $\mathrm{C}_{2}$.

\begin{tabular}{|c|c|c|c|c|c|c|c|c|}
\hline No. & $\begin{array}{l}\text { Section stake } \\
\text { number }(\mathrm{m})\end{array}$ & $\begin{array}{c}\text { Multipoint } \\
\text { extensometer } \\
\text { number }\end{array}$ & $\begin{array}{c}\text { Buried } \\
\text { instrument } \\
\text { elevation }(\mathrm{m})\end{array}$ & $\begin{array}{l}\text { Exposed } \\
\text { elevation } \\
\text { of } C_{2}(m)\end{array}$ & $\begin{array}{c}\text { Vertical distance } \\
\text { between } \\
\text { instrument and } \\
\mathrm{C}_{2}(\mathrm{~m})\end{array}$ & $\begin{array}{c}\text { Duration of } \\
\text { sudden increase } \\
\text { in deformation }(d)\end{array}$ & $\begin{array}{c}\text { Displacement } \\
\text { increment }(\mathrm{mm})\end{array}$ & $\begin{array}{c}\text { Average } \\
\text { displacement } \\
\text { growth rate } \\
(\mathrm{mm} / \mathrm{d})\end{array}$ \\
\hline 1 & $0+077.3$ & $\mathrm{M}_{\mathrm{ZC}} 0+077-7$ & 570 & 567.9 & 2.1 & 5 & 12.74 & 2.55 \\
\hline 2 & $0+101.0$ & $\mathrm{M}_{\mathrm{ZC}} 0+101-1$ & 582 & 570 & 12 & 7 & 6.70 & 0.96 \\
\hline 3 & $0+124.0$ & $\mathrm{M}_{\mathrm{ZC}} 0+124-3$ & 574.5 & 572 & 2.5 & 7 & 30.43 & 4.35 \\
\hline 4 & $0+153.3$ & $\mathrm{M}_{\mathrm{ZC}} 0+153-7$ & 576.7 & 575 & 1.7 & 5 & 37.47 & 7.49 \\
\hline 5 & $0+181.0$ & $\mathrm{M}_{\mathrm{ZC}} 0+181-2$ & 579.9 & 579 & 0.9 & 7 & 12.82 & 1.42 \\
\hline
\end{tabular}

Figures 6(a) and 6(b). With the continuous excavation of the main powerhouse, the cracks developed slowly. After the excavation of the main powerhouse was completed, the change in cracking was not obvious. During the excavation of layer X of the main powerhouse in May 2018, the shotcrete layer cracks along $\mathrm{C}_{2}$ on the main powerhouse sidewall were mainly distributed in the sections from stakes $\mathrm{ZCO}+057 \mathrm{~m}$ to $\mathrm{ZC} 0+077 \mathrm{~m}, \mathrm{ZC} 0+107 \mathrm{~m}$ to $\mathrm{ZC} 0+163 \mathrm{~m}$, and $\mathrm{ZC} 0+308 \mathrm{~m}$ to $\mathrm{ZC} 0+316 \mathrm{~m}$. The width of the cracks was $0.3-2 \mathrm{~cm}$, and the total extension length was $78 \mathrm{~m}$, accounting for $17.8 \%$ of the main powerhouse length.

3.3. Shear Deformation in the Omnibus Bar Caves. During the excavation, many parts of the omnibus bar caves were affected by $\mathrm{C}_{2}$, which produced shear deformation. To monitor the dislocation and deformation of $\mathrm{C}_{2}$ during the excavation process, inclinometers $\mathrm{IN}_{\mathrm{ZMD}}-0+023-1$ and $\mathrm{IN}_{\mathrm{ZMD} 4}-0+025-1$ passing through $\mathrm{C}_{2}$ were buried in the bottom plates of omnibus bar caves \#3 and \#4, respectively, near the powerhouse side. The buried positions are shown in Figure 7(a). Figure 7(b) shows the shear deformation curves measured by the two inclinometers. As shown in Figure 7(b), in February 2017, during the excavation of layer VI of the powerhouse, the upper and lower walls of $\mathrm{C}_{2}$ exhibited shear dislocation deformation, and the deformation increased continuously. In April 2017, the deformation increased sharply, the deformation measured by the two instruments reached maximum values of $52.91 \mathrm{~mm}$ and $30.43 \mathrm{~mm}$, and then the deformation decreased. After the excavation of layer VII of the powerhouse, the deformation value gradually tended to converge. Finally, the shear deformation values measured by the two inclinometers were $38.32 \mathrm{~mm}$ and $26.38 \mathrm{~mm}$.

In addition to the shear deformation, cracks in the spray concrete also appeared in the \#6-8 omnibus bar cave. The cracks were distributed intermittently along $C_{2}$, and the spray concrete fell off at some local locations. Most of the meshed steel bars were exposed at the cracked parts of the spray concrete, and purple tuff could be seen in some places. The characteristics and distribution of cracking failure of a typical spray layer are shown in Figure 8(a). As shown in Figure 8(a), the cracking and destruction of the sprayed layer of the omnibus bar caves began in October 2016. At that time, the excavation of the sidewall of layer $\mathrm{V}$, which intersected with the omnibus bar caves of the main power house, was in progress. Most of the cracks were steep and inclined toward the powerhouse. The cracks in the sidewall of the omnibus bar caves near the powerhouse side and the exposed parts of $\mathrm{C}_{2}$ were relatively dense. At the same time, the phenomena of spray layer shedding and block falling also appeared near $\mathrm{C}_{2}$. As the excavation of the sidewall of the powerhouse reached layer VI, the spraying layer fell off again around $\mathrm{C}_{2}$, and new cracks appeared on the sidewall of the omnibus bar caves. The backfill concrete of the replacement tunnels, which were arranged along $\mathrm{C}_{2}$ and intersected with the sidewall of the \#5-7 omnibus bar caves, also cracked. The cracks inclined to the side of the powerhouse, with a strike of $\mathrm{N} 20^{\circ}-60^{\circ} \mathrm{E}$, a dip direction of SE, and a dip angle of $50^{\circ}-75^{\circ}$. As shown in Figure 8(c), the length of the cracks was $1-4 \mathrm{~m}$, the width was generally $1-3 \mathrm{~mm}$, and the width of a few cracks was up to $15 \mathrm{~mm}$.

After the lining of omnibus bar cave \#8 was constructed, the lining concrete cracked under the influence of $\mathrm{C}_{2}$. The cracks were mainly distributed $25 \mathrm{~m}$ away from the powerhouse and close to the side of the powerhouse. Cracks mainly developed in the bottom plate, and a few of them were located in the sidewall or in a circular direction. Most of the cracks ran through the bottom plate. The length of the cracks was 3-9 $\mathrm{m}$, and the width was $1-10 \mathrm{~mm}$. Most of the cracks on the sidewall sloped steeply toward the side of the powerhouse. The cracks in the bottom plate were approximately perpendicular to the axis of the omnibus bar cave, and the circumferential cracks ran through the arch crown and the sidewalls on both sides, as shown in Figure 8(b). In addition, some dislocations occurred in the cracking positions of the concrete of the bottom plate, and these dislocations were mainly located at crack (2). Vertical and horizontal dislocations occurred on both sides of the crack, resulting in the bottom plate close to the main transformer room being higher than that near the powerhouse.

In general, support was generally carried out in time after excavation. With the excavation of the powerhouse, $\mathrm{C}_{2}$ was gradually exposed. In this process, the shotcrete cracking occurred in the main powerhouse and omnibus bar caves. Lining concrete cracking occurred in the omnibus bar caves and replacement tunnel 2\#. The large deformation occurred near $\mathrm{C}_{2}$ of the downstream sidewall in the main powerhouse. In addition, rock mass collapses occurred in the main powerhouse, transformer chamber, omnibus bar caves, tailrace surge chamber, and other caverns. Based on the field monitoring and analysis, it was found that when $\mathrm{C}_{2}$ was located $5 \mathrm{~m}$ below the excavation face of the sidewall, the shear deformation increased rapidly. After $C_{2}$ was 

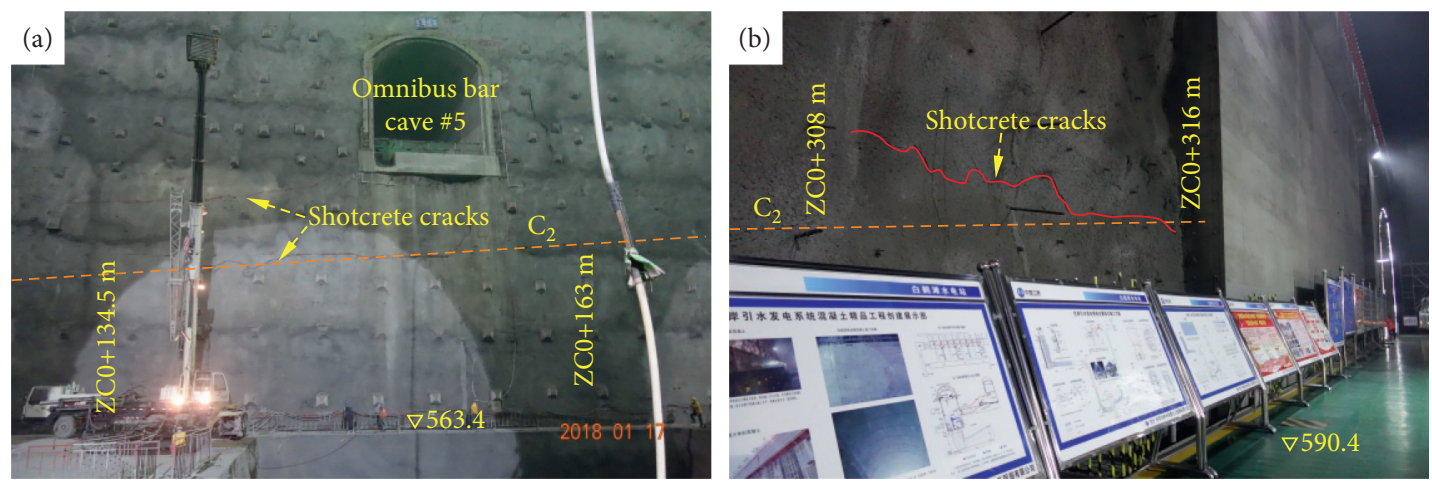

FIGURE 6: Shotcrete cracking of the main powerhouse downstream sidewall: (a) the section from stake ZC0 + $134.5 \mathrm{~m}$ to ZC0 + $163 \mathrm{~m}$; (b) the section from stake $\mathrm{ZC} 0+308 \mathrm{~m}$ to $\mathrm{ZC} 0+316 \mathrm{~m}$.

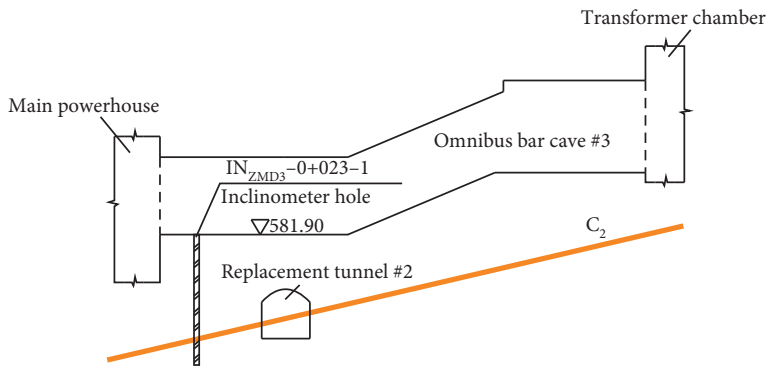

(a)

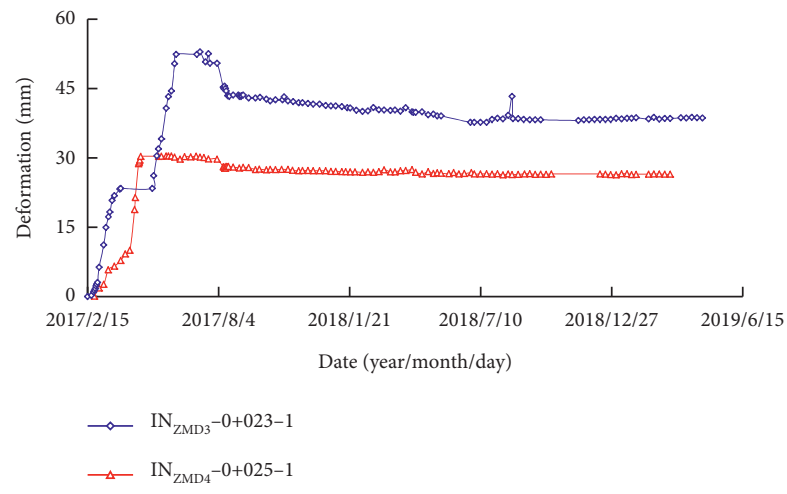

(b)

FIGURE 7: The layout of the inclinometer and the measured deformation-time curves $\left(\mathrm{IN}_{\mathrm{ZMD} 4}\right.$ refers to omnibus bar cave \#4 and $0+025-1$ refers to the number of inclinometers): (a) layout of the inclinometer in omnibus bar cave \#3; (b) shear deformation deformation-time curves measured by the inclinometers in the omnibus bar caves.

completely exposed for a period of time, the deformation tended to converge.

\section{Failure Mechanism Analysis}

The deformation and failure of the surrounding rock mass in the powerhouse affected by $\mathrm{C}_{2}$ were the result of multiple factors, such as the characteristics of $\mathrm{C}_{2}$, in situ stress, rock mass structure, and excavation disturbance, and involved a complex rock mass response due to excavation unloading. To analyze the problems of rock mass deformation and failure caused by $\mathrm{C}_{2}$, two deformation failure modes, rock collapse and shear deformation, were proposed. The increase in sidewall deformation in the main powerhouse, shear deformation in the omnibus bar caves, and shotcrete cracks on the main powerhouse sidewall were attributed to shear deformation of the interlayer shear zone. This study also verified the effect of shear deformation of $\mathrm{C}_{2}$ by using 3DEC and the data measured by inclinometers and multipoint extensometers. The mechanical mechanisms of these two deformation failure modes were analyzed.

4.1. Rock Collapse Mechanism. Many unstable blocks formed under the combined cutting action of $\mathrm{C}_{2}$ and dense joints in the upper and lower rock masses. These unstable rock masses relaxed under the action of strong unloading and eventually collapsed and fell. Thus, rock mass collapse occurred along $\mathrm{C}_{2}$ in the main powerhouse, omnibus bar caves, and other caverns. Collapse failure of the sidewall is common in large caverns, for example, in the main powerhouse and the tailrace surge chambers where $\mathrm{C}_{2}$ is exposed, and it occurred in the upper and lower rock masses of $\mathrm{C}_{2}$. The failure mechanism of the $\mathrm{C}_{2}$ footwall rock collapse at the arch crown of the omnibus bar caves is shown in Figures 9(a) and 9 (b). The typical failure mechanism of sidewall rock collapse along $C_{2}$ is shown in Figure 9(c).

$\mathrm{C}_{2}$ developed in the middle part of the $P_{2} \beta_{2}^{4}$ tuff layer, and the tuff rock is relatively weak. After long-term tectonic action in geological history, shear joints perpendicular to the strike of the strata were created in the tuff rock. In the $\mathrm{C}_{2}$ parent rock, steep joints, cylindrical fractures, and gently inclined fractures developed. Thus, the integrity of the local area adjacent to $\mathrm{C}_{2}$ is poor. $\mathrm{C}_{2}$ is located at the upper part of the arch crown of omnibus bar cave \#8, and it was exposed at the arch crown on both sides of the omnibus bar cave near the main powerhouse and transformer chamber. The collapse of the arch crown occurred in the rock mass of the $\mathrm{C}_{2}$ footwall at the section from stake $\mathrm{ZC} 0+040 \mathrm{~m}$ to $\mathrm{ZC} 0+053 \mathrm{~m}$ (Figure 9(a)). The surrounding rock mass 


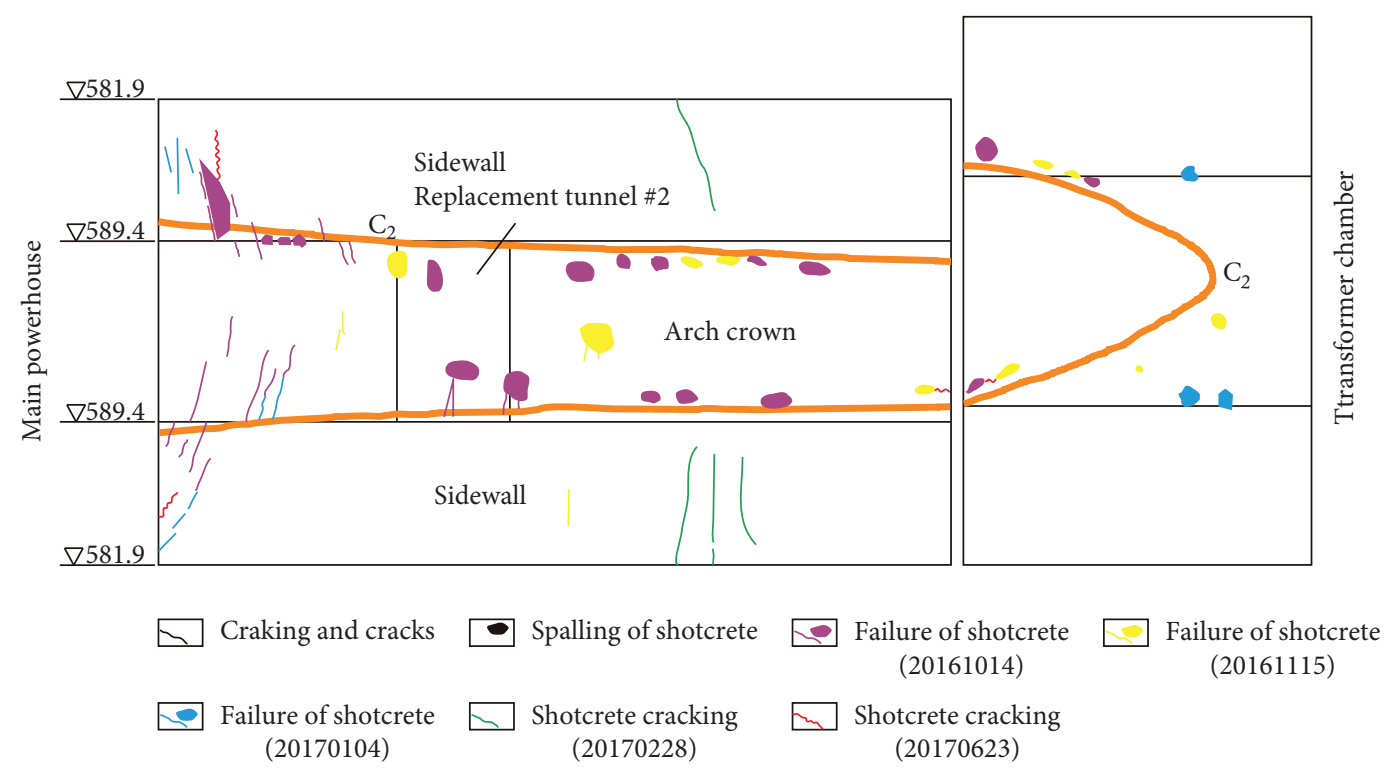

(a)
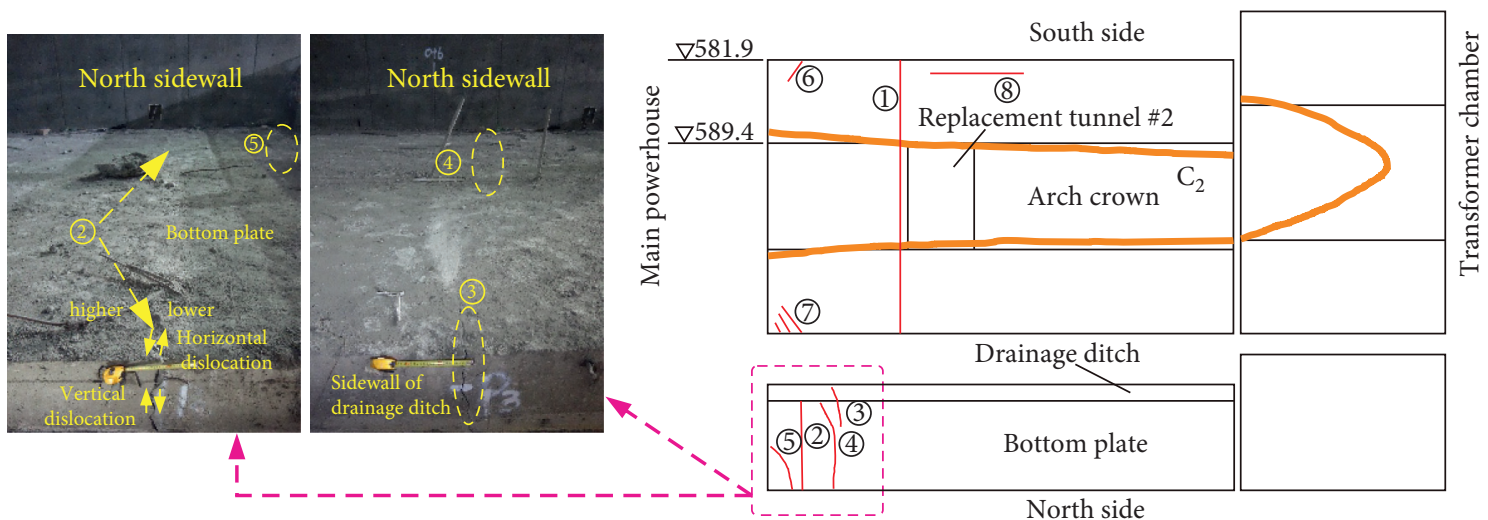

(b)

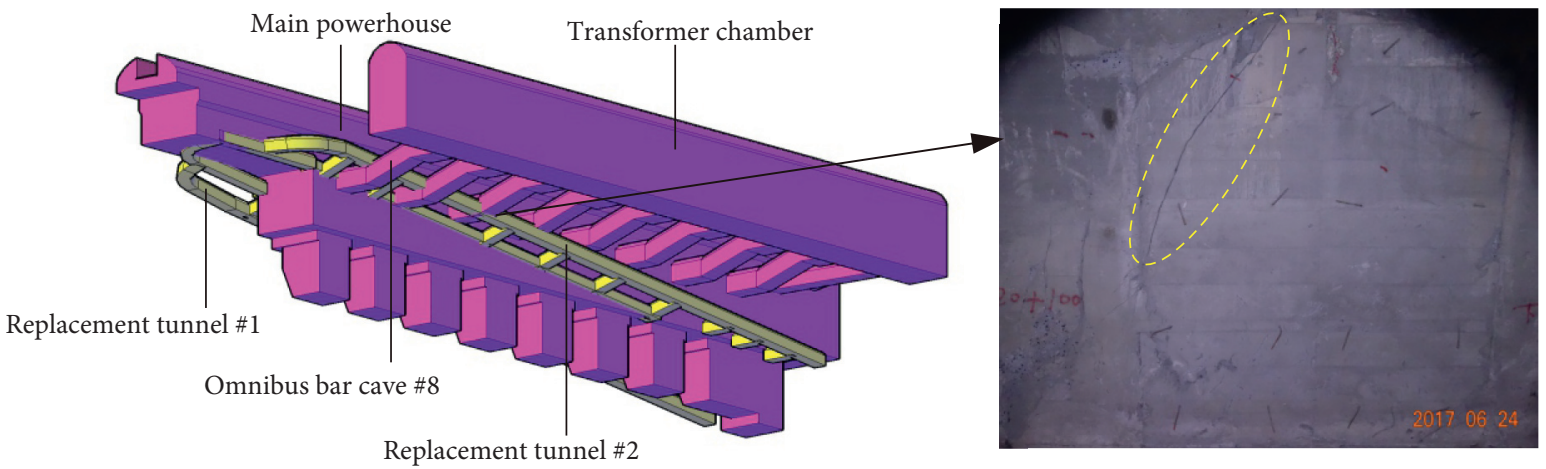

(c)

FIGURE 8: Failure in omnibus bar caves and replacement tunnel \#2: (a) distribution diagram of failure of shotcrete in omnibus bar cave \#8; (b) distribution of cracks in the lining concrete of omnibus bar cave \#8; (c) cracking in the backfill concrete of replacement tunnel \#2.

affected by $\mathrm{C}_{2}$ belongs to class IV, characterized by the development of dense joint fractures and poor rock mass integrity. Moreover, the thickness of the $\mathrm{C}_{2}$ footwall rock mass is relatively thin, and it easily loosens during the excavation and unloading process. As shown in Figure 9(b), the rock mass is cut by the combination of the structural surfaces and the free faces, creating a number of loose blocks that will eventually cause collapse.

Before the excavation of the powerhouse, the surrounding rock was in a three-dimensional stress equilibrium under a high ground stress environment. During the excavation of the powerhouse, the constraints of the excavated 


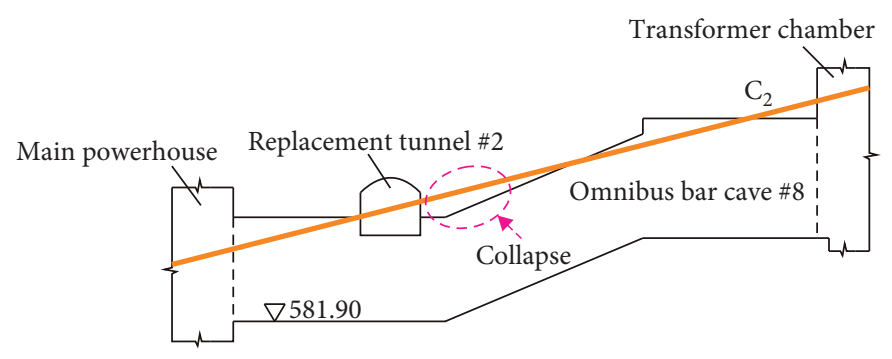

(a)

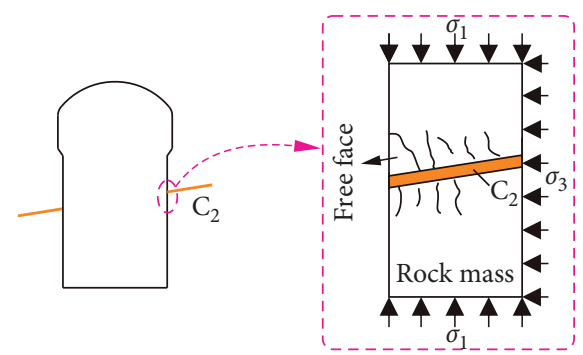

(c)

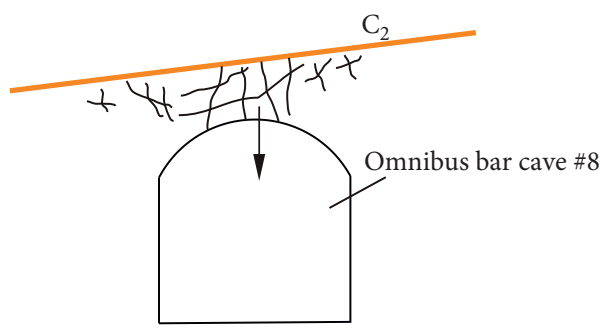

(b)

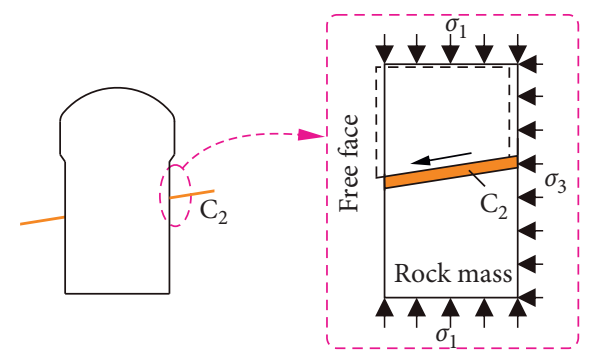

(d)

FIGURE 9: Mechanism diagrams of rock collapse and shear deformation: (a) schematic diagram of the spatial position relationship between omnibus bar cave $\# 8$ and $\mathrm{C}_{2}$; (b) mechanism diagram of the collapse along $\mathrm{C}_{2}$ of surrounding rock mass at the arch crown; (c) mechanism diagram of the collapse and failure along $\mathrm{C}_{2}$ of the surrounding rock mass of the cavern sidewalls; (d) mechanism diagram of the shear slip failure along $\mathrm{C}_{2}$ of the main powerhouse sidewall.

rock mass on the retained rock mass of the excavated contour surface were rapidly removed, and the stress was adjusted and redistributed due to unloading. The vertical stress $\sigma_{1}$ of the surrounding rock near the cavity surface of the sidewall increased, and the horizontal stress $\sigma_{3}$ decreased, so that the rock mass near the excavation was in an approximately bidirectional stress state. Upon the release of radial stress and concentration of circumferential stress, the steep fractures in the upper and lower walls of $\mathrm{C}_{2}$ developed further. The combination of cracks, steep and gently inclined fractures, free faces, and upper and lower interfaces of $\mathrm{C}_{2}$ cut the rock mass into a series of unstable blocks. Due to disturbances of continuous excavation and blasting vibrations, the blocks continued to be loosened. Under the action of gravity or further disturbance, the rock blocks will eventually slip or fall into the tunnels (Figure 9(c)).

In addition, groundwater also contributed to the occurrence of rock collapse. On-site investigations found that the exposed part of $\mathrm{C}_{2}$ was wet and there were locations with dripping water. $\mathrm{C}_{2}$ consists of mud and rock debris, and it exhibits water softening potential, as do the upper and lower wall tuff. In the presence of groundwater, $\mathrm{C}_{2}$ and tuff tend to soften and become mud, which further reduces the strength and integrity of the rock mass, thus increasing the possibility of collapse. Construction disturbance also has a certain influence on collapse. The excavation period of a large-scale powerhouse is long, and the procedure is complex. The disturbance of large-scale excavation blasting on the rock mass is strong and lasting. Adjacent excavation may impact blasting vibrations, which aggravate the loosening and collapse of unstable blocks.
4.2. Shear Deformation Mechanism. $\mathrm{C}_{2}$ originated as a permanent deformation trace of a layered rock mass subjected to shear during tectonic movement. This shows that during the long period of geological history, the upper and lower wall rock masses in the staggered zone have undergone shear slip movement. In the process of excavating and unloading the large-scale underground powerhouse, it is possible for shear dislocations to accelerate in the interlayer shear zone. Unfortunately, during the excavation of the Baihetan left bank underground powerhouse, shear dislocation occurred along $\mathrm{C}_{2}$. As a result, obvious shear deformation occurred on the sidewall of the main powerhouse and the surrounding rock of the omnibus bar caves, and cracks appeared on the shotcrete of the main powerhouse, replacement tunnels, and omnibus bar caves.

3DEC is discrete element software based on Newton's second law that can generate models containing discrete blocks and weak structural surfaces. The blocks contact one another through points, edges, and surfaces according to the structural plane and are not subject to the coordination constraint of displacement. Therefore, the blocks can be separated and rotated relatively, and the displacement between blocks is discontinuous. Under the initial conditions, the block has its own position and is in a state of force balance. Under the action of excavation, due to the change in stress and displacement constraints, the stress balance is broken, resulting in displacement. The force and moment of the block can be obtained from Newton's second law to calculate the motion state of the block. Then, the new position state and motion state of the block are calculated and circulated until all blocks reach a new equilibrium state to 
simulate the mechanical response and motion of the blocks [32-34]. 3DEC can be used to simulate the deformation and failure of rock masses cut by structural surfaces during excavation and unloading. Therefore, to further study the shear slip effect of $\mathrm{C}_{2}, 3 \mathrm{DEC}$ software was selected to simulate the excavation of the Baihetan left bank powerhouse. In order to reduce the influence of size effect and consider the distribution of the surrounding caverns, the large possible range is used for calculation. This research established a $553 \mathrm{~m} \times 456 \mathrm{~m} \times 280 \mathrm{~m}$ (main powerhouse axis $\times$ water flow direction $\times$ vertical direction) domain of the underground powerhouse for numerical simulation. The elevation of $450 \mathrm{~m}$ was considered the bottom boundary, and 3505 blocks and 99600 zones were generated in 3DEC. The blocks were piled to form the overall model and then embedded in the structural planes to build the left bank underground powerhouse excavation model (Figures 10(a) and 10(b)). In the simulation, the block constitutive model and joint constitutive model based on Mohr-Coulomb strength criterion were mainly used to simulate hard basalt and soften $\mathrm{C}_{2}$. In order to simplify the calculation model, the mechanical parameters of surrounding rock $\mathrm{III}_{1}$ with the largest proportion were mainly considered for calculation. The mechanical parameters of the surrounding rock and structural plane used in the simulation calculation are listed in Table 2. It should be noted that all the parameters were based on laboratory or in situ testing. The aforementioned mechanical parameters were the modulus $(E)$, cohesion $(c)$, and internal friction angle $(\varphi)$ of the rock mass and the shear zone. The initial stress of Baihetan underground powerhouse site was mainly measured by the stress relief and hydrofracturing technique methods. According to the fieldmeasured values, we found that there was a functional relationship between the initial stress distribution and buried depth in the underground cavern area on the left bank, as shown in Table 3. The stress distribution function in Table 3 was used for the simulation in this study. The excavation simulation was carried out layer by layer from top to bottom with reference to the actual construction of the Baihetan left bank underground powerhouse (Figure 1).

The results of the excavation simulation calculated by 3DEC software and the displacement distribution of the $0+153 \mathrm{~m}$ section measured by the multipoint extensometers are shown in Figure 11. As shown in Figure 11, the surrounding rock of the downstream sidewall of the powerhouse showed discontinuous deformation along $\mathrm{C}_{2}$. Figures 11(b) and 11(c) show the displacement distribution of the $\mathrm{ZC} 0+153 \mathrm{~m}$ section calculated by $3 \mathrm{DEC}$ simulation and measured by field multipoint extensometers, respectively. These figures show that the general deformation distribution characteristics were consistent. Shear slip occurred at the downstream sidewall of the main powerhouse along $\mathrm{C}_{2}$, and the closer to it leaded to the large deformation of the downstream sidewall near $\mathrm{C}_{2}$. For upstream and downstream sidewall points close to $C_{2}$, both the numerical simulation results and the field measurements showed that the displacement of the downstream sidewall point was larger than that of the upstream sidewall point near $\mathrm{C}_{2}$ on the different sections. Due to the special structure and low shear strength of $\mathrm{C}_{2}$, the deformation rate of the downstream sidewall caused by shear slip was larger than that of the upstream sidewall caused by excavation unloading. Therefore, the displacement measured by the multipoint extensometers on the sidewall increased suddenly. At the same time, the sliding of the hanging wall rock mass of $\mathrm{C}_{2}$ also caused shear dislocation in the surrounding rock of the omnibus bar cave. The shear deformation measured by the inclinometers buried in the omnibus bar caves is shown in Figures 7 and 12. As shown in Figure 12, the upper and lower wall rock masses were staggered at the $\mathrm{C}_{2}$ position, and there were also different degrees of inclination in the vertical direction. In addition, from the shear deformation curves measured by the inclinometers and the displacement-time curves measured by the multipoint extensometers, it can be seen that the shear deformation started to converge after a period of growth and did not show aging characteristics. The creep deformation of $\mathrm{C}_{2}$ is not obvious.

As $\mathrm{C}_{2}$ cut through the main powerhouse at a gentle inclination angle, the sidewall excavation fully exposed $C_{2}$, and it obliquely intersected the sidewall by a larger angle. At that time, the parent rock was free of lateral constraints, and the hanging wall rock mass was in an unstable state similar to a dip slope and had a tendency to slide freely toward the free faces. Because the weak interlayer material had poor bond strength, the shear strength of the staggered zone was very low, and shear slip was likely to occur. In addition, the direction of the initial major principal stress on the upstream side of the main powerhouse was roughly the same as the potential slip direction of $\mathrm{C}_{2}$. Due to the large unloading rate along the principal stress direction, the upper rock mass of $\mathrm{C}_{2}$ would also be disturbed by strong unloading. With the excavation of the sidewall of the main powerhouse, the high ground stress was released instantaneously. Upon strong unloading, the hanging wall rock mass of $\mathrm{C}_{2}$ slid toward the free faces, resulting in dislocations and large deformation. Its failure mechanism is shown in Figure 9(d).

Under the influence of the shear dislocation of the upper and lower walls of the $\mathrm{C}_{2}$ rock mass, the downstream sidewall of the main powerhouse and the surrounding rock of the omnibus bar caves showed shear slip against the free faces. At the same time, the displacement measured by the multipoint extensometers buried in the sidewall of the main powerhouse increased abruptly, and the shear deformation measured by the inclinometers buried in the omnibus bar caves was $26.38-38.32 \mathrm{~mm}$. The multipoint extensometers that showed a sudden increased displacement were all buried in the hanging wall rock mass close to $\mathrm{C}_{2}$. After $\mathrm{C}_{2}$ was exposed for a period of time, the hanging wall rock mass of $\mathrm{C}_{2}$ sheared along the free faces with the unloading of confining pressure and stress adjustment, resulting in discontinuous deformation along $\mathrm{C}_{2}$ of the surrounding rock of the downstream sidewall.

Affected by the shear slip of the upper wall rock mass of $\mathrm{C}_{2}$, a sudden increase in deformation then occurred at the surrounding rock of the powerhouse sidewall where $\mathrm{C}_{2}$ was exposed. As a result, the shotcrete swelled and cracked at that location (Figures 6 and 8). There was a similarity between the location of the cracks and that of the displacement 


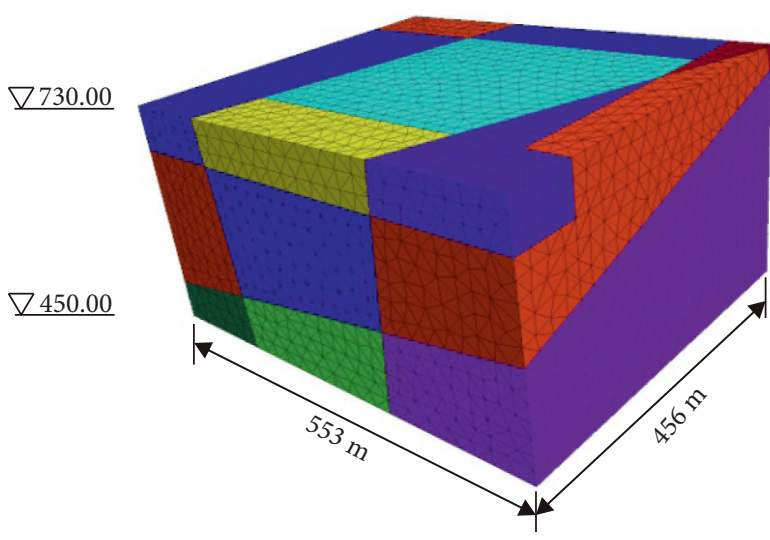

(a)

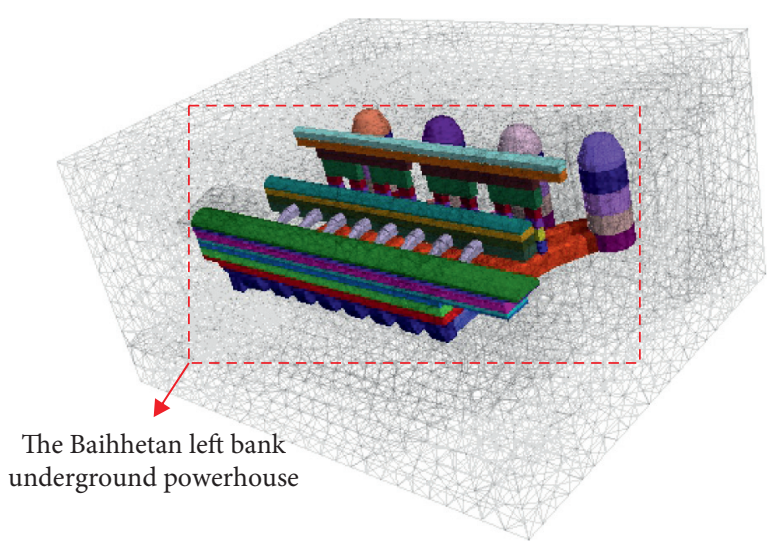

(b)

FIGURE 10: Underground powerhouse model and excavation layer diagram on the left bank of Baihetan: (a) integral model of the left bank underground powerhouse; (b) schematic diagram of excavation layers of the left bank underground powerhouse.

TABLE 2: Mechanical parameters of the surrounding rock and $\mathrm{C}_{2}$.

\begin{tabular}{lccc}
\hline Name & $E(\mathrm{GPa})$ & $c(\mathrm{MPa})$ & $\varphi\left(^{\circ}\right)$ \\
\hline Surrounding rock & 11 & 1.3 & 47.7 \\
$\mathrm{C}_{2}$ & 0.19 & 0.02 & 19.5 \\
\hline
\end{tabular}

TABLE 3: Initial stress distribution of the left bank underground powerhouse area.

\begin{tabular}{lc}
\hline Initial stress $(\mathrm{MPa})$ & Left bank underground powerhouse \\
\hline$\sigma_{1}$ & $\sigma_{1}=0.0304 \mathrm{~h}+10.5$ \\
$\sigma_{2}$ & $\sigma_{2}=0.0255 \mathrm{~h}+7.6$ \\
$\sigma_{3}$ & $\sigma_{3}=0.028 \mathrm{~h}$ \\
\hline
\end{tabular}

mutation measured by the multipoint extensometers on the sidewall. The cracks extended along $\mathrm{C}_{2}$, and these multipoint extensometers were also distributed along $\mathrm{C}_{2}$. Additionally, due to the shear dislocation between the upper and lower rock masses of $\mathrm{C}_{2}$ and the surrounding rock mass deformation, shotcrete cracking and concrete cracking occurred in the omnibus bar caves. At the same time, shear deformation of the backfill concrete occurred in replacement tunnel \#2. In addition, $\mathrm{C}_{2}$ is flexible and plastic and may expand when encountering water infiltration. Therefore, under the influence of unloading confining pressure and other factors, plastic extrusion deformation occurred in $\mathrm{C}_{2}$ toward the free face. This phenomenon also led to the expansion and cracking of shotcrete at the exposed $\mathrm{C}_{2}$.

\section{Discussion}

Starting from the engineering characteristics of $\mathrm{C}_{2}$, this paper summarized the rock mass deformation and failure problems caused by $\mathrm{C}_{2}$ from three aspects: rock collapse, large deformation and shotcrete cracking in the main powerhouse, and shear deformation in omnibus bar caves. The problems in the last two factors were attributed to the shear deformation of the interlayer shear zone. In this study, the mechanisms of rock collapse and shear deformation were analyzed. This research comprehensively summarized the rock mass deformation and failure problems caused by $\mathrm{C}_{2}$ during the whole excavation process and classified these problems into two types of deformation failure, namely, rock collapse and shear deformation.

Not only does Baihetan Hydropower Station have unfavorable geological structures such as $\mathrm{C}_{2}$, but many hydropower stations have unfavorable geological structures that affect the stability of surrounding rock of underground powerhouses [35]. The deformation and failure problems caused by poor geological structures similar to $\mathrm{C}_{2}$ in a few different hydropower stations are shown in Table 4 [9, 36-41]. This study mainly compared the deformation and failure of the Baihetan, Jinping I, and Dagangshan hydropower stations affected by adverse geological conditions. Li et al. [9] analyzed the monitoring data of the multipoint extensometers and the excavation damaged zones (EDZs) of two sections, $\mathrm{K} 0+31.7 \mathrm{~m}$ and $\mathrm{K} 0+126.8 \mathrm{~m}$, in the Jinping I underground powerhouse. They showed that the deformations in section $\mathrm{K} 0+126.8 \mathrm{~m}$ were larger, especially along the downstream sidewall of the main transformer chamber where there was a fault $f_{18}$ and an intrusive weakness dike $X$, with a maximum deformation $236.7 \mathrm{~mm}$. Since a fault $f_{14}$ cut the rock mass at section $\mathrm{K} 0+126.8 \mathrm{~m}$, the EDZ of this section was usually greater than that of section $\mathrm{K} 0+31.7 \mathrm{~m}$, especially around the upstream high side wall, which increased the instability of surrounding rock. In the Baihetan left bank underground powerhouse, the displacement measured by several multipoint extensometers arranged along $\mathrm{C}_{2}$ in the downstream sidewall (the section from stake $\mathrm{ZC} 0+077 \mathrm{~m}$ to $\mathrm{ZC0}+181 \mathrm{~m}$ ) increased sharply from August 2 to 9, 2017. It could be seen that the existence of fault or interlayer shear zone may induce large deformation of surrounding rock during the excavation of the underground powerhouse. Shen et al. [37] indicated that the existence of diabase dikes $\left(\beta_{80}, \beta_{81}, \beta_{163}, \beta_{164}\right.$, etc.) induced rock mass collapse and rock block fall problems during excavation of Dagangshan underground powerhouse. For example, a $3,000 \mathrm{~m}^{3}$ volume rock mass collapsed at a diabase dike $\beta_{80}$ at the arch during the first excavation step of the 

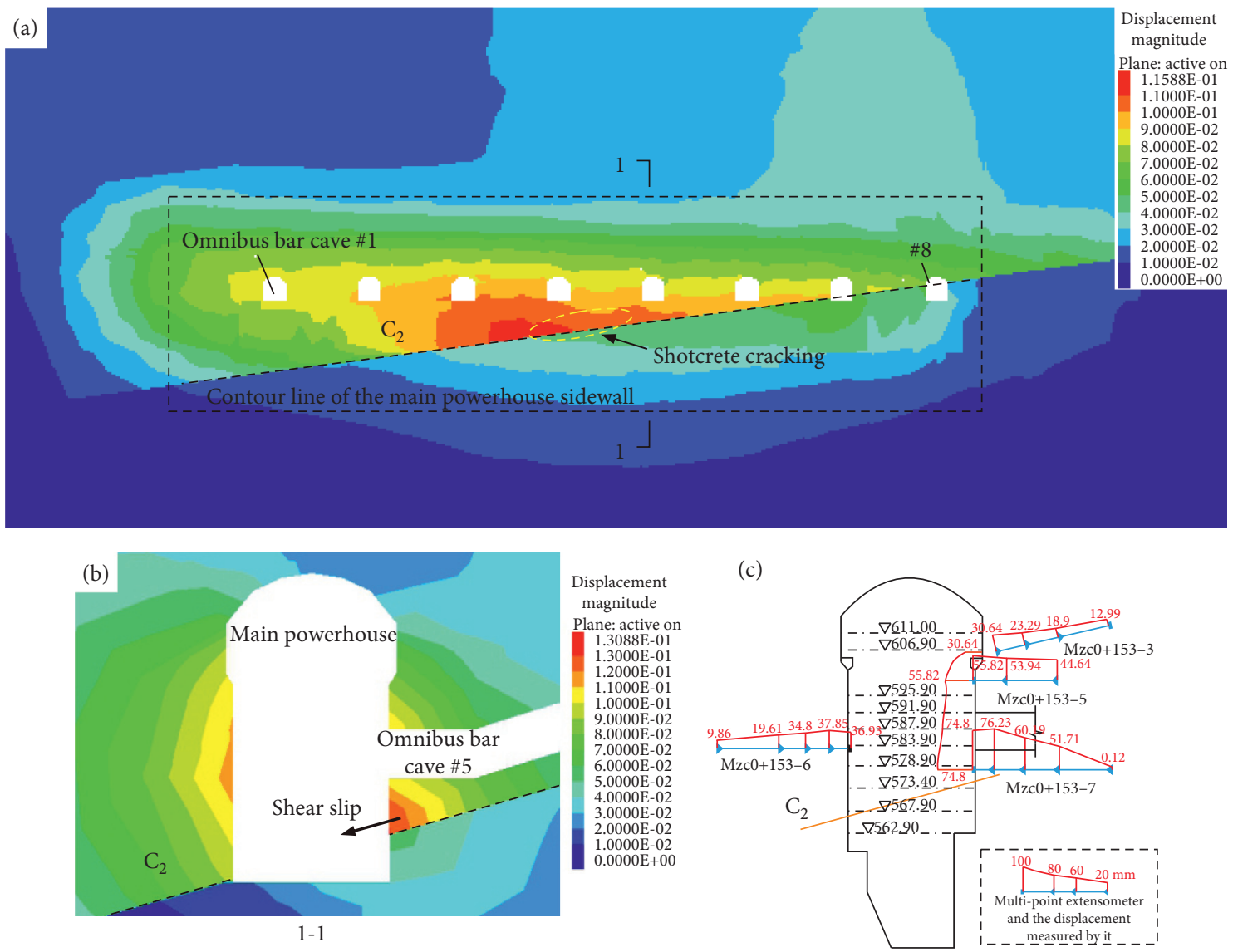

FIGURE 11: The deformation results of the 3DEC simulation calculation and the deformation measured by the multipoint extensometers: (a) the deformation distribution along the axis direction of the main powerhouse calculated by 3DEC software; (b) the deformation distribution along the ZC0 $+153 \mathrm{~m}$ section calculated by 3DEC software; (c) the displacement distribution of the ZC $0+153 \mathrm{~m}$ section measured by the multipoint extensometers in January 2020.

Dagangshan main powerhouse, which caused a long construction delay [38]. In the Baihetan left bank underground powerhouse, rock collapses have occurred in the exposed parts of $\mathrm{C}_{2}$ in many caverns, including the main powerhouse and the main transformer chamber. Because $\mathrm{C}_{2}$ or diabase dikes are weak zones in the underground powerhouse, they can combine with other faults or cracks and form unstable blocks. These blocks may collapse under the action of excavation disturbance or their own weight. The above comparison showed that when the underground powerhouse has an interlayer shear zone or other similar bad geological conditions, problems such as deformation, collapse, and shear slippage may occur during the excavation of the caverns.

In recent years, many scholars have studied the displacement and deformation of the surrounding rock of the power station caverns. Abdollahipour and Rahmannejad [42] studied the influence of the ratio of transverse stress to vertical stress and the section shape of the cavern on the cavern stability and the sidewall displacements and proposed a method to predict the displacement of key points on the sidewall. Rajabi et al. [43] studied and predicted the maximum horizontal displacement of the power station cavern by using an artificial neural model. Rezaei and Rajabi $[44,45]$ predicted the vertical displacement of the roof and floor of the powerhouse cavern and the plastic zone around the cavern through numerical simulation and other tools. These studies are similar to this study in that all included a deformation numerical simulation of the underground powerhouse. All the numerical simulation results showed the common characteristic that the displacements of key points in caverns may be large when the comprehensive properties of the rock mass are poor and the cavern scale is large. The difference was that these scholars focused mainly on establishing prediction models of the deformation of the key points or plastic zones in the underground caverns, whereas this study focused mainly on the characteristics and mechanism analysis of the failure problems such as deformation and rock collapse caused by $\mathrm{C}_{2}$ during the whole excavation of the left bank underground powerhouse. The two-dimensional FEM program Phase $^{2}$ was used in these other numerical simulations, and they assumed that the rock mass was isotropic, homogeneous, and continuous. In this study, 3DEC was mainly used to help analyze the shear deformation mechanism, and the rock mass was regarded as a discontinuous discrete medium. Wang et al. [46] studied the large deformation and failure mechanism analysis of the multi-free-face surrounding rock mass in the Baihetan 

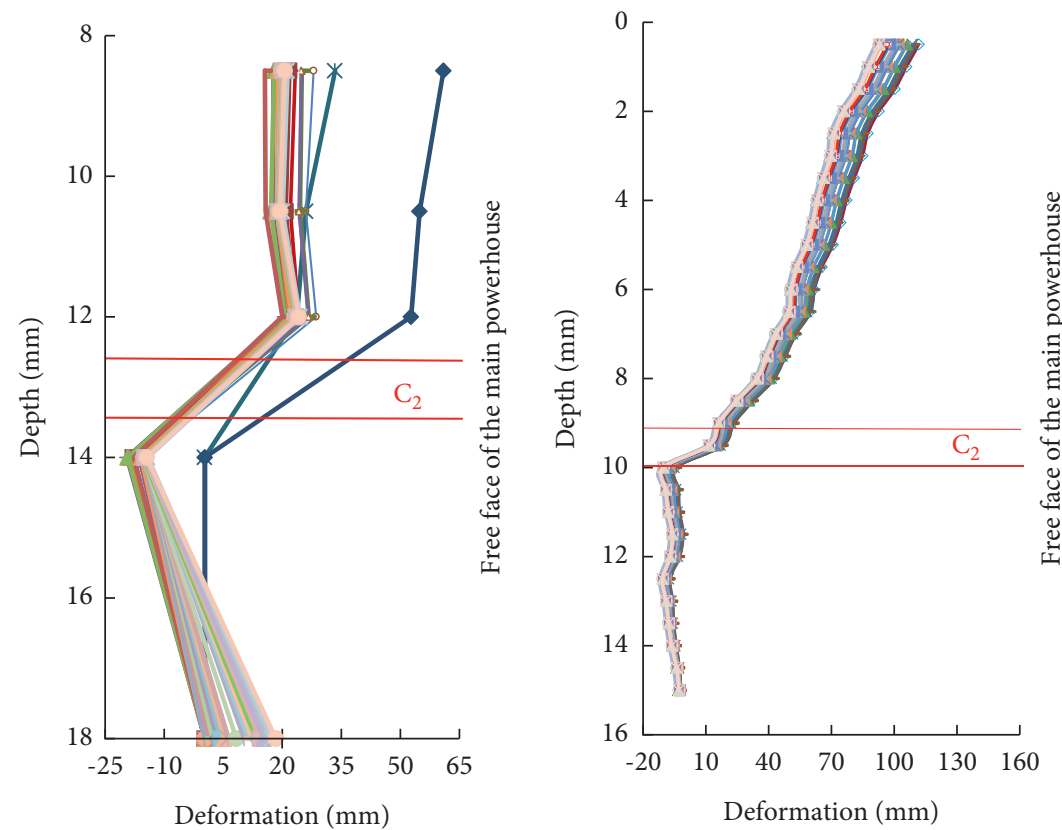

\begin{tabular}{|c|c|c|}
\hline-201 & 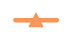 & 25 \\
\hline $2017 / 7 / 7$ & & $2018 / 8 / 28$ \\
\hline $2017 / 8 /$ & & $2018 / 9 / 26$ \\
\hline $2017 / 9 / 21$ & & $2018 / 11$ \\
\hline $2018 / 1 / 30$ & 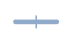 & $2018 / 11 / 2$ \\
\hline $2018 / 4 / 25$ & 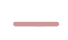 & $2018 / 12 /$ \\
\hline $2018 / 6 / 2$ & & 2018/1 \\
\hline
\end{tabular}

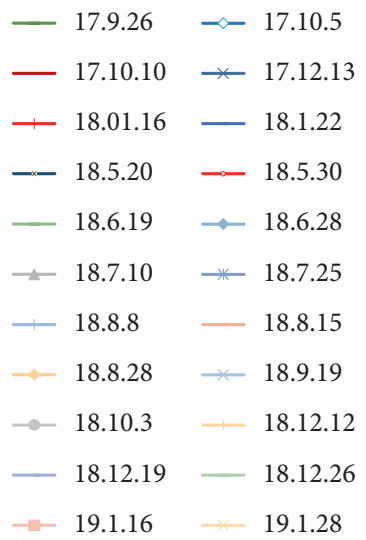

(a)

(b)

FIgURE 12: The curves of shear deformation with depth measured by inclinometers in the omnibus bar caves: (a) $\mathrm{IN}_{\mathrm{ZMD}}-0+023-1$; (b) $\mathrm{IN}_{\mathrm{ZMD}^{-}}-0+025-1$.

TABLE 4: Deformation and failure issues and the corresponding poor geological structures in different hydropower stations [9, 36-41].

\begin{tabular}{|c|c|c|}
\hline Project name & Main poor geological structures & $\begin{array}{l}\text { Deformation and failure affected by these geological } \\
\text { structures }\end{array}$ \\
\hline $\begin{array}{l}\text { Baihetan (left } \\
\text { bank) }\end{array}$ & $\begin{array}{c}\mathrm{C}_{2} \text { : Composed of mud and rock fragments with } \\
\text { characteristic large-scale extension, shear slip, and water } \\
\text { softening }\end{array}$ & $\begin{array}{l}\text { Rock collapses, large deformation and shotcrete cracking } \\
\text { in the main powerhouse, and shear deformation in the } \\
\text { omnibus bar caves }\end{array}$ \\
\hline Jinping I & $\begin{array}{l}\text { Three faults }\left(f_{13}, f_{14} \text {, and } f_{18}\right) \text { : mainly composed of } \\
\text { cataclastic rock, breccia, mylonite, etc. and general class IV } \\
\text { surrounding rock; X: a small dike of mica-plagioclase } \\
\text { lamprophyre that intruded into the marble at a later stage, } \\
\text { generally broken and with poor self-stability }\end{array}$ & $\begin{array}{l}\text { Spalling, large deformation of the surrounding rock mass, } \\
\text { and shotcrete layer cracking }\end{array}$ \\
\hline Dagangshan & $\begin{array}{l}\text { Diabase dike }(\beta) \text { : strong orientation, crushed interior, } \\
\text { strong alteration, parallel alignment, poor contact with } \\
\text { surrounding rocks, and complicated distributions }\end{array}$ & Collapse and rock block fall \\
\hline Shuangjiangkou & $\begin{array}{l}\text { Porphyry vein: generally broken and poor self-stability, } \\
\text { shear slip characteristics }\end{array}$ & $\begin{array}{c}\text { Shear deformation of the top arch, cracking at the junction } \\
\text { of the veins and homogeneous rock }\end{array}$ \\
\hline Guandi & $\begin{array}{l}\text { Staggered zones }(\mathrm{f} \times 3-15, \mathrm{f} \times 4-25, \mathrm{f} \times 4-22 \text {, etc.): mainly } \\
\text { composed of crushed rock, quartz vein and calcite vein, } \\
\text { class III, IV structural planes }\end{array}$ & Rock collapses, shotcrete cracking \\
\hline
\end{tabular}


underground powerhouse. Both Wang et al.'s study and this research were based on field-measured displacement data to analyze the deformation and failure mechanism. The difference was that Wang et al. mainly studied the influence of multi-free-face surrounding rock on the deformation and failure of caverns during the excavation, while this study mainly focused on the deformation and failure caused by $\mathrm{C}_{2}$ in the left bank powerhouse.

To reduce the adverse effects of $\mathrm{C}_{2}$ on the stability of the surrounding rock of the main powerhouse and other caverns, some cracking-restraint design methods for large underground caverns could be applied $[15,20,21,47,48]$. On the one hand, it was very necessary to construct concrete replacement tunnel in advance. A deep replacement shear tunnel and shallow shear branch tunnel were constructed before the main powerhouse excavation. These tunnels were mainly used to replace and reinforce $\mathrm{C}_{2}$ and its influence zone on both the upstream and downstream sides of the main powerhouse. The replacement tunnels were arranged along $\mathrm{C}_{2}$ with a diameter of $6.0 \mathrm{~m} \times 6.0 \mathrm{~m}$, and the sidewalls of the replacement tunnels were approximately $13 \mathrm{~m}$ away from the sidewall of the main powerhouse. The layout of the replacement tunnels and branch tunnels is shown in Figure 8(c). During the excavation of the main powerhouse, to control the sudden adjustment of stress in the exposure process of $\mathrm{C}_{2}$, the excavation sequence was optimized in layers and parts. On the other hand, the upper and lower walls of $\mathrm{C}_{2}$ were reinforced by locking and systematic anchor cables. In particular, a series of supporting measures were taken, including adjusting the length and spacing of the sidewall anchor cables and adding anchor cables to the large shear deformation parts. In addition, the repair technology of weak interlayer based on microbially induced calcium carbonate precipitation can also be considered for application. At the same time, multipoint extensometers, borehole television, acoustic emission monitoring, and microseismic monitoring technology can be used to monitor the surrounding rock of underground powerhouse during construction. Multiple monitoring methods could ensure timely feedback before the failure of the surrounding rock induced by $\mathrm{C}_{2}$ [49-52]. Through these targeted reinforcement measures, the deformation and failure caused by $\mathrm{C}_{2}$ of the powerhouse and omnibus bar cave could be obviously controlled.

\section{Conclusions}

The rock mass deformation and failure problems caused by $\mathrm{C}_{2}$ during excavation of the Baihetan left bank underground powerhouse were summarized in this study, and the characteristics and mechanisms of these problems were analyzed based on field monitoring and numerical calculation. The following can be concluded:

(1) The field investigation and related experimental analysis showed that $\mathrm{C}_{2}$ had low cohesion and shear strength and $\mathrm{C}_{2}$ was extensively exposed in the left bank underground powerhouse.

(2) The rock mass deformation and failure problems induced by $\mathrm{C}_{2}$ in the Baihetan left bank underground powerhouse consisted of three aspects: rock collapse, large deformation and shotcrete cracking in the main powerhouse, and shear deformation in the omnibus bar caves.

(3) Based on field monitoring and 3DEC numerical calculation, this study revealed that two failure modes of rock collapse and shear deformation were induced under the influence of $\mathrm{C}_{2}$, high ground stress, and other factors. These mainly caused rock collapses, shotcrete cracking, and large deformation to occur during the exposure of $\mathrm{C}_{2}$ in many caverns.

(4) Since interlayer shear zones similar to $C_{2}$ can pose great potential risks to the construction of the project, relevant reinforcement measures should be considered in advance in the design and construction to possibly eliminate the adverse effects of the interlayer shear zones.

\section{Data Availability}

All the underlying data supporting the results are included within the manuscript.

\section{Conflicts of Interest}

The authors declare that they have no conflicts of interest.

\section{Acknowledgments}

The authors gratefully thank the National Natural Science Foundation of China (11902210) and the Graduate Student's Research Innovation Foundation of Sichuan University (2018YJSY076) for their support.

\section{References}

[1] S. Q. Duan, Q. Jiang, D. P. Xu, and G. F. Liu, "Experimental study of mechanical behavior of interlayer shear zone under cyclic loading and unloading condition," International Journal of Geomechanics, vol. 20, no. 3, 2020.

[2] S. Q. Duan, Q. Jiang, G. F. Liu et al., "An insight into the excavation-induced stress paths on mechanical response of weak interlayer zone in underground cavern under high geostress," Rock Mechanics and Rock Engineering, vol. 54, no. 3, pp. 1-24, 2021.

[3] D. Xu, X. Feng, Y. Cui, and Q. Jiang, "Use of the equivalent continuum approach to model the behavior of a rock mass containing an interlayer shear weakness zone in an underground cavern excavation," Tunnelling and Underground Space Technology, vol. 47, pp. 35-51, 2015.

[4] D. Xu, X. Feng, and Y. Cui, "A simple shear strength model for interlayer shear weakness zone," Engineering Geology, vol. 147-148, pp. 114-123, 2012.

[5] D. P. Xu, X. T. Feng, Y. J. Cui, Y. L. Jiang, and K. Huang, "A comparative study on the shear behavior of an interlayer material based on laboratory and in situ shear tests," Geotechnical Testing Journal, vol. 35, no. 3, pp. 375-386, 2012.

[6] J. D. Rogers, The Failure of the Lower Colorado River Dam at Austin, pp. 147-160, World Environmental \& Water Resources Congress, TX, USA, 2015. 
[7] P. Duffaut and J. Larouzée, "Geology, engineering and humanities: three sciences behind the Malpasset dam failure (France, 2 december 1959)," The Quarterly Journal of Engineering Geology and Hydrogeology, vol. 52, no. 4, pp. 445-458, 2019.

[8] A. Bolla, P. Paronuzzi, D. Pinto, D. Lenaz, and M. D. Fabbro, "Mineralogical and geotechnical characterization of the clay layers within the basal shear zone of the 1963 vajont landslide," Geosciences, vol. 10, no. 9, 2020.

[9] H. Li, M. Liu, W. Xing, S. Shao, and J. Zhou, "Failure mechanisms and evolution assessment of the excavation damaged zones in a large-scale and deeply buried underground powerhouse," Rock Mechanics and Rock Engineering, vol. 50, no. 7, pp. 1883-1900, 2017.

[10] Y. Zhang, J. He, Y. Wei, and D. Nie, "Prediction research of deformation modulus of weak rock zone under in-situ conditions," Journal of Mountain Science, vol. 8, no. 2, pp. 345-353, 2011.

[11] F. Huang, H. Zhu, Q. Xu, Y. Cai, and X. Zhuang, "The effect of weak interlayer on the failure pattern of rock mass around tunnel-s," Tunnelling and Underground Space Technology, vol. 35, pp. 207-218, 2013.

[12] D. P. Xu, X. T. Feng, and Y. J. Cui, “An experimental study on the shear strength behaviour of an interlayered shear weakness zone," Bulletin of Engineering Geology and the Environment, vol. 72, no. 3-4, pp. 327-338, 2013.

[13] Z. L. Ding, Q. Q. Wang, and J. Wang, "Analysis on stability of an Arch Dam with interlayer shear zones," KSCE Journal of Civil Engineering, vol. 20, no. 6, pp. 2262-2269, 2015.

[14] Z. Cui, Q. Sheng, and X. Leng, "Control effect of a large geological discontinuity on the seismic response and stability of underground rock caverns: a case study of the baihetan \#1 surge chamber," Rock Mechanics and Rock Engineering, vol. 49, no. 6, pp. 2099-2114, 2016.

[15] S. Duan, X. Feng, Q. Jiang, G. Liu, S. Pei, and Y. Fan, "In situ observation of failure mechanisms controlled by rock masses with weak interlayer zones in large underground cavern excavations under high geostress," Rock Mechanics and Rock Engineering, vol. 50, no. 9, pp. 2465-2493, 2017.

[16] Z. Zhou, M. Lin, Q. Guo, and M. Chen, "Scale effect and value criterion of the permeability of the interlayer staggered zones in the basalt of Jinsha River basin, China," Hydrogeology Journal, vol. 26, no. 5, pp. 1731-1748, 2018.

[17] Q. N. Guo and J. W. Huang, "Analysis of the influence of the interlayer shear zone in the basalt of Jinsha River Basin on the main buildings," IOP Conference Series: Earth and Environmental Science, vol. 113, 2018.

[18] J. Zhao, X. Feng, Q. Jiang, and Y. Zhou, "Microseismicity monitoring and failure mechanism analysis of rock masses with weak interlayer zone in underground intersecting chambers: a case study from the Baihetan Hydropower Station, China," Engineering Geology, vol. 245, pp. 44-60, 2018.

[19] P. Cheng, X. B. Wan, D. Fang, and L. Q. Li, "Influence of interlayer staggered zone on the stability of surrounding rock of baihetan hydropower station underground powerhouse," Water Resources and Power, vol. 37, no. 1, pp. 115-118, 2019, in Chinese.

[20] D. Liu, A. Shao, H. Li, C. Jin, and Y. Li, "A study on the enhancement of the mechanical properties of weak structural planes based on microbiologically induced calcium carbonate precipitation," Bulletin of Engineering Geology and the Environment, vol. 79, no. 8, pp. 4349-4362, 2020.

[21] C. Jin, D. Liu, A. Shao et al., "Study on healing technique for weak interlayer and related mechanical properties based on microbially-induced calcium carbonate precipitation," PLoS One, vol. 13, no. 9, Article ID e0203834, 2018.

[22] A. Shi, Y. Wei, J. Wu, D. Ren, and M. Tang, "Study on the shear deformation of intralayer shear bands at the Baihetan hydropower station dam foundation," Bulletin of Engineering Geology and the Environment, vol. 79, no. 7, pp. 3517-3532, 2020.

[23] Z. Liu, C. Zhang, C. Zhang, Y. Gao, H. Zhou, and Z. Chang, "Deformation and failure characteristics and fracture evolution of cryptocrystalline basalt," Journal of Rock Mechanics and Geotechnical Engineering, vol. 11, no. 5, pp. 990-1003, 2019.

[24] S. Y. Zhu, C. D. He, F. Peng, A. C. Shi, D. Y. Yuan, and W. K. Zhang, "Experimental and numerical studies on the mechanical properties of columnar jointed basalt," Advances in Civil Engineering, vol. 2020, Article ID 6659718, 14 pages, 2020.

[25] D. P. Xu: Study on the shear strength or interlayer shear weakness zone and its effect on the overall stability of cavern group, Ph.D. thesis, Institute of Rock and Soil Mechanics, Chinese Academy of Sciences, Wuhan, China. 2011, in Chinese.

[26] G. Han, H. Zhou, J. L. Chen et al., "Engineering geological properties of interlayer shear zones at Baihetan hydropower station," Rock and Soil Mechanics, vol. 4, no. 9, pp. 3559-3568, 2019, in Chinese.

[27] Ministry of Housing and Urban-Rural Development of the People's Republic of China, Code for Hydropower Engineering Geology, Ministry of Housing and Urban-Rural Development of the People's Republic of China, Beijing, China, 2016, in Chinese.

[28] Z. T. Bieniawski, "Engineering classification of jointed rock masses," Transactions of the South African Institution of Civil Engineers, vol. 15, pp. 335-343, 1973.

[29] M. Z. Xiang, Engineering Rock Mass Classification of Baihetan Hydroelectric Station at Jinsha River, Chengdu University of Technology, Chengdu, China, 2009, in Chinese.

[30] Q. Jiang, X. T. Feng, H. Zhou et al., "Discussion of strength value for interlayer shear belt," Rock and Soil Mechanics, vol. 32, no. 11, pp. 3379-3386, 2011, in Chinese.

[31] S. Q. Duan, X. T. Feng, and Q. Jiang, "Study of failure modes and mechanisms for rock masses with staggered zones of Baihetan underground caverns under high geostress," Chinese Journal of Rock Mechanics and Engineering, vol. 36, no. 4, pp. 852-864, 2017, in Chinese.

[32] C. Shi, W. J. Chu, and W. T. Zheng, Numerical Simulation Technology and Engineering Application of Block Discrete Element, China Construction Industry Press, Beijing, China, 2016, in Chinese.

[33] L. J. Dong, J. H. Wang, X. B. Li, and K. Peng, "Dynamic stability analysis of rockmass: a review," Advances in Civil Engineering, vol. 2018, Article ID 4270187, 22 pages, 2018.

[34] T. Wang, B. W. Fan, and S. S. Khadka, "Flowchart of DEM modeling stability analysis of large underground powerhouse caverns," Advances in Civil Engineering, vol. 2020, Article ID 8874120, 15 pages, 2020.

[35] A. Wu, Q. Yang, X. Ding, H. Zhou, and B. Lu, "Key rock mechanical problems of underground powerhouse in Shuibuya hydropower station," Journal of Rock Mechanics and Geotechnical Engineering, vol. 3, no. 1, pp. 64-72, 2011.

[36] Q. Qian and X. Zhou, "Failure behaviors and rock deformation during excavation of underground cavern group for jinping I hydropower station," Rock Mechanics and Rock Engineering, vol. 51, no. 8, pp. 2639-2651, 2018. 
[37] Y. J. Shen, G. L. Xu, and J. N. Yi, “A systematic engineering geological evaluation of diabase dikes exposed at the underground caverns of Dagangshan hydropower station, Southwest China," Environmental Earth Sciences, vol. 76, no. 14, 2017.

[38] M. Wang, J. W. Zhou, A. C. Shi, J. Q. Han, and H. B. Li, "Key factors affecting the deformation and failure of surrounding rock masses in large-scale underground powerhouses," $A d$ vances in Civil Engineering, 2020.

[39] D. Zhang, S. J. Li, D. P. Xu et al., "Investigation on deformation and cracking behaviors and stability analysis of surrounding rock mass during the preliminary excavation of underground main powerhouse of Shuangjiangkou hydropower station," Chinese Journal of Rock Mechanics and Engineering, vol. 40, no. 3, pp. 520-532, 2021, in Chinese.

[40] Y. Zhang, P. X. Xiao, X. L. Ding et al., "Study of deformation and failure characteristics for surrounding rocks of underground powerhouse caverns under high geostress condition and countermeasures," Chinese Journal of Rock Mechanics and Engineering, vol. 31, no. 2, pp. 228-244, 2012, in Chinese.

[41] B. Lu, X. L. Ding, Z. H. Dong, and A. Q. Wu, "Stability analysis of determined blocks in the underground powerhouse of guandi hydropower station," in Proceedings of the 10th International Conference on Advances in Discontinuous Numerical Methods and Applications in Geomechanics and Geoengineering ICADD, vol. 10, pp. 219-225, Honolulu, HI, USA, 2012.

[42] A. Abdollahipour and R. Rahmannejad, "Investigating the effects of lateral stress to vertical stress ratios and caverns shape on the cavern stability and sidewall displacements," Arabian Journal of Geosciences, vol. 6, no. 12, pp. 4811-4819, 2013.

[43] M. Rajabi, R. Rahmannejad, and M. Rezaei, "Evaluation of the maximum horizontal displacement around the power station caverns using artificial neural network," Tunnelling and Underground Space Technology, vol. 64, pp. 51-60, 2017.

[44] M. Rezaei and M. Rajabi, "Vertical displacement estimation in roof and floor of an underground powerhouse cavern," Engineering Failure Analysis, vol. 90, pp. 290-309, 2018.

[45] M. Rezaei and M. Rajabi, "Assessment of plastic zones surrounding the power station cavern using numerical, fuzzy and statistical models," Engineering with Computers, vol. 37, no. 2, pp. 1499-1518, 2019.

[46] M. Wang, H. Li, and J. Han, "Large deformation evolution and failure mechanism analysis of the multi-freeface surrounding rock mass in the Baihetan underground powerhouse," Engineering Failure Analysis, vol. 100, pp. 214-226, 2019.

[47] Q. Fan, Z. Wang, W. He, and P. Lin, "Technological innovations in construction of underground caverns in basaltic rocks at Baihetan Hydropower Station on Jinsha River," SCIENTIA SINICA Technologica, vol. 51, no. 9, pp. 1088-1106, 2021, in chinese.

[48] Q. Jiang, X. T. Feng, S. J. Li, G. S. Su, and Y. X. Xiao, "Cracking-restraint design method for large underground caverns with hard rock under high geostress condition and its practical application," Chinese Journal of Rock Mechanics and Engineering, vol. 38, no. 6, pp. 1081-1101, 2019, in chinese.

[49] P. W. Xiao, B. Qian, P. Jiang, N. W. Xu, and B. Li, "Deformation forecasting of surrounding rock mass based on correlation between frequency and fracture scale of microseismicity," Advances in Civil Engineering, 2018.

[50] L. G. Zhang, D. Wang, and J. Dong, "Assessment of the excavation damaged zones in the surrounding rock of an underground powerhouse under high in situ stress using an acoustic velocity detecting method," Advances in Civil Engineering, vol. 2020, Article ID 7297260, 13 pages, 2020.

[51] G. L. Feng, X. T. Feng, B. R. Chen, Y. X. Xiao, and Y. Yu, "A microseismic method for dynamic warning of rockburst development processes in tunnels," Rock Mechanics and Rock Engineering, vol. 48, no. 5, pp. 2061-2076, 2015.

[52] G. L. Feng, B. R. Chen, Q. Jiang, Y. X. Xiao, W. J. Niu, and P. X. Li, "Excavation-induced microseismicity and rockburst occurrence: similarities and differences between deep parallel tunnels with alternating soft-hard strata," Journal of Central South University, vol. 28, no. 2, pp. 582-594, 2021. 